\title{
ERŐDÍTÉS ZALAVÁR-VÁRSZIGETEN RÉGI ÁSATÁSOK - ÚJ EREDMÉNYEK
}

\author{
GERGELY KATALIN*
}

The study addresses problems of chronology based on a re-assessment of the section cut through the rampart of the fort at Zalavar -Vársziget, of the rampart's structural traits and of its function within the context of the settlement, as well as through the analysis of the recovered finds and the results of the dendrochronogical analyses.

Keywords: Carolingian Age, Árpádian Age, stronghold, earth-wood fortification with an outer stone wall, Zalavár-Vársziget

A tanulmány a Zalavár-Várszigetet övező erődités átvágásának újraértelmezésével: a sánc szerkezeti jellegzetességeinek és településszerkezeti összefüggéseinek felülvizsgálatával, valamint az elökerült leletanyag elemzésével és a dendrokronológiai eredmények bevonásával taglalja a keltezés problémáit.

Kulcsszavak: Karoling-kor, Árpád-kor, sáncvár, fa-föld szerkezetü erödítés külső kőfallal, Zalavár-Vársziget

1951-ben, a rendszeres zalavári ásatások kezdetén a Vársziget geodéziai felmérése során kirajzolódott a sziget tényleges kiterjedése, peremén az egykori erődítés nyomaival. ${ }^{1}$ Az erődítést négy ponton kutatóárokkal - korabeli szóhasználattal „várfalmetszettel” 2 - vágták át. Az ásatás vezetője, Fehér Géza és Cs. Sós Ágnes irányították az I. számú sáncátvágást, míg a zalavári „,kutatócsoport" tagjaként Vargha László néprajzos,

* A kézirat érkezett: 2015. március 31.

* Gergely Katalin. MTA Bölcsészettudományi Kutatóközpont Régészeti Intézet, 1014 Budapest, Úri u. 49.; gergely.katalin@ btk.mta.hu; Magyar Nemzeti Múzeum, 1088 Budapest, Múzeum krt. 14-16.; gergely.katalin@hnm.hu

1 Cs. Sós 1963, 11

2 Az erődítés kutatásának leírásakor a dokumentációban és a publikációban használt eredeti kifejezéseket vettem át, úgymint: sáncátvágás, várfalmetszet, külső vár, belső vár stb. építész a II. számú, Méri István pedig a III. és IV. jelzésú átvágásokat. A kijelölt kutatóárkok így az L alakú sziget déli (I., IV.) és keleti (II.) nyúlványáról, valamint északnyugati (III.) szegletéről nyújtanak információt (1. kép). ${ }^{3}$ Az erődítés kutatását 1973-tól a Vársziget északkeleti részén folytatta Cs. Sós Ágnes. Ezek a kutatások meróben más módszerrel zajlottak: a kutatóárkok - összefüggő, nagy felületet alkotva - teljes felületében tárták fel az erődítést. ${ }^{4}$

3 Cs. Sós 1963, Karte 1.

4 A téma a szerző doktori disszertációjának részét képezi. A feldolgozás lehetőségéért és a hasznos szakmai tanácsokért köszönettel tartozom Ritoók Ágnesnek és témavezetőmnek, Szőke Béla Miklósnak. A kutatás az OTKA 111853 program keretében valósul meg. 


\section{I. sáncátvágás ${ }^{5}$}

A Vársziget déli részén, az ún. „homokgödörtől” K-re eső területen a külső várfal kutatására 1951 és 1954 között elsőként megnyitott, 17×1,5 méteres kutatóárokban, majd a hozzá kapcsolt szel- vényekben (É/15, É/10, É/14, É/19, É/25, É/26, É/27) több egymás mellett futó falat, körítófalat és erődítésszakaszt, cölöprendszert sikerült megfogni, ezek révén pedig a Vársziget különböző korú erődítési rendszereit elkülöníteni (1-2. kép).

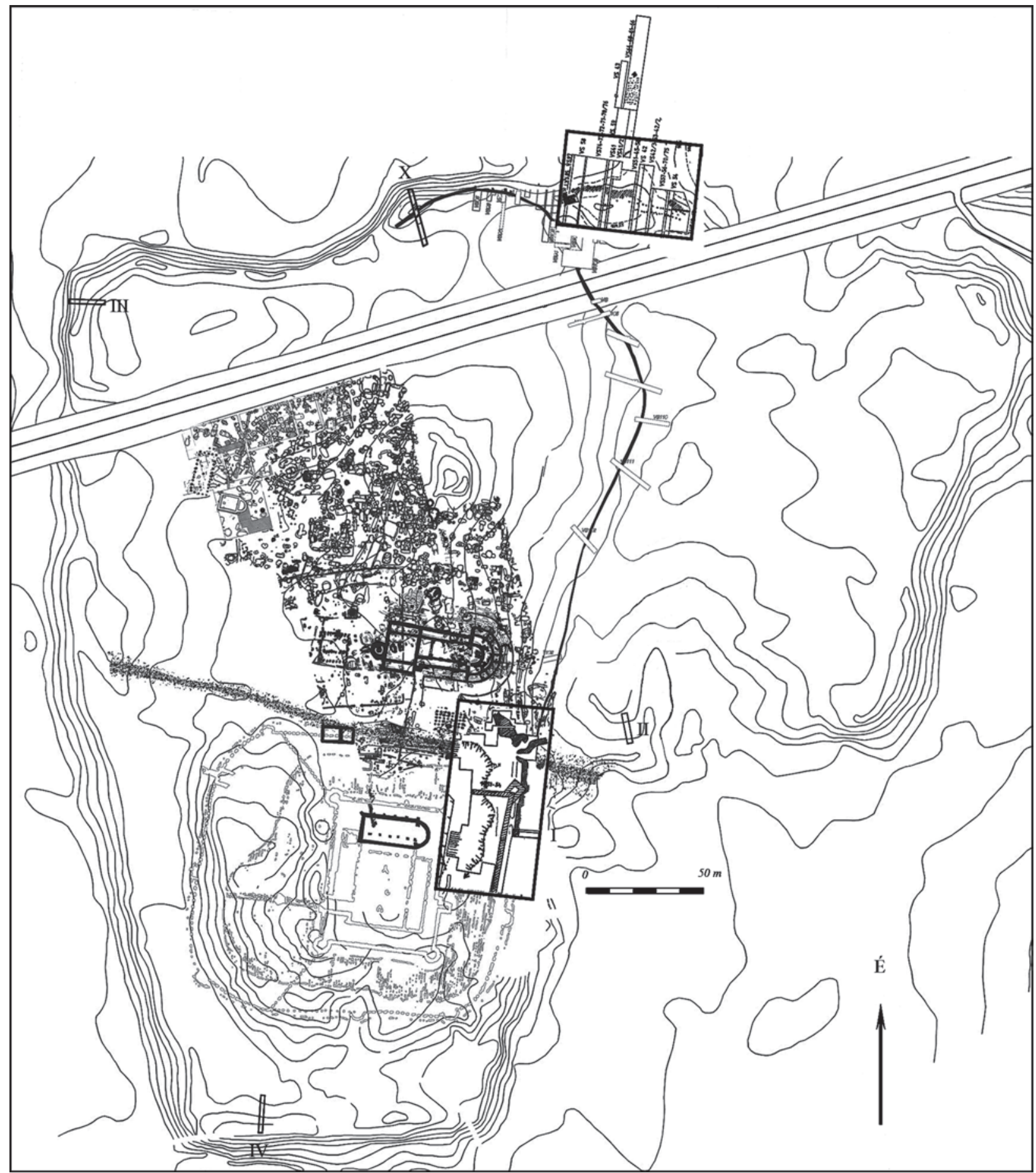

1. kép. Zalavár-Vársziget, összesítő térkép. Kiemelve az erődítéskutatás helyszínei; X: faminták helye (SzŐKE 2014 nyomán) Abb. 1. Zalavár-Vársziget, Gesamtplan. Die Orte der Befestigungsforschungen markiert, die Lage der Holzresten mit $X$ angegeben (nach SZÖKE 2014)

5 Cs. Sós 1963, 119-120, Karte 3, 7. 


\section{II. sáncátvágás ${ }^{6}$}

A bolygatatlan körülményeknek köszönhetően a sziget D-i peremén lehetett legvilágosabban megfigyelni és értelmezni a külsó eródítés szerkezetét. Az erődítést kívülről egy kb. 1,5 m széles, szárazon rakott kőfal, a sziget felóli belső oldalán pedig egy három párhuzamos cölöpsorból álló, földdel kitöltött szerkezet és egy rácsos gerendázat alkotja. A kőfalat kívülről kisebb cölöplyukak sora kísérte.

\section{III. sáncátvágás ${ }^{7}$}

A szigetet övező külső erődítés átvágását a sziget É-i szélén folytatták, kezdetben Méri István, majd Vargha László vezetésével. Ezen a szakaszon több apró eltéréssel az előzőhöz igen hasonló szerkezetet figyeltek meg. A sánc külső frontját jelentő kövekből szárazon rakott köpenyfal alapozása 1,5-2 m szélességben és kb. fél méter magasságban jelentkezett. Omladéka több méter széles sávban terült szét. A cölöpsorok közé fogott alsó gerendázat hálószerkezetet rajzolt ki, amelynek közeit döngölt agyagos és mocsárihomokos földdel töltötték ki. További különbség a II. számú átvágáshoz képest, hogy ezen a szakaszon a mocsár felé egy a fal irányával megegyezően lefektetett gerendát és két ferdén bevert támasztókaró nyomát is feltárták.

\section{IV. sáncátvágás ${ }^{8}$}

Az L alakú sziget délre nyúló szárának végén, a sziget legdélebbi szakaszán húzott kutatóárok is hasonló szerkezetet mutatott, bár itt sem a keresztirányú alsó gerendaszerkezet, sem külső támaszték vagy partvédelmi rendszer nyomait nem találták. A sáncot egy kettős, illetve hármas cölöprendszer alkotta, amelynek magját döngölt agyagos rétegek töltötték ki 2 méter magasságban. Kőomladék két helyen és mélységben mutatkozott: a döngölt agyagos réteg felett, közvetlenül a vékony humuszréteg alatt, maximum 1 méter mélységben, keskenyebben, valamint ennek leszakadó, lejtős folytatásában, feltehetően a sánc külső vonalát jelző lábánál, mint egy kövezett "padka”, szélesebben.

\section{A kapu ${ }^{9}$}

A külső fal kutatására nyitott szelvénysor feltárása során a sánc kőfalának kapuzatát is megtalálták. A kapu az L alakú sziget szárainak találkozásában, a keleti és déli szigetrész elágazásában fekszik. A külső várfal ezen a ponton derékszögben megtörik, befelé nyíló 4,8-5,8 m hosszú, egymástól 1,7-3,3 m távolságra lévő kapuszárnyakat képez.

\section{VS41-VS103 kutatóárkok ${ }^{10}$}

Cs. Sós Ágnes a sziget északi részén tett megfigyelései megerősítették a korábbi sáncátvágások eredményeit, és részben ki is egészítették azokat (3. kép). A külső várfalat nagy felületben elsőként mindenütt a szélesen elterült kőomladék jelezte, amely mintegy $30 \mathrm{~m}$ széles sávra terjedt ki, és az egykori fal mindkét oldalán szétterült. Az ásatási terület szinte teljes hosszán egy nagyon határozottan jelentkező, kettős cölöpsor húzódik végig, amelyet további, rendszerbe nem illő, kisebb karó- és oszlophelyek kísérnek. A sáncalapozás gerendarácsozatára, illetve deszkázatára csak egy szakaszon, a VS58-VS84 közötti területen találtak rá. A gerendaszerkezet mérete 3,5×4 m volt, amely kb. 45 fokos szöget zárt be a fallal, folytatásában pedig, szintén a fal belső oldalán, annak vonalával párhuzamosan fektetett deszkázatot lehetett megfigyelni. A külső vár vonalán kívül egy észak felé tartó, több tíz méter hosszan és legalább öt méter széles sávban (a VS60-VS69 területén) súrún és látszólag rendszertelenül levert, apró karókat észleltek, amelyeket a partvédelmi rendszer részeként értelmezett a feltáró.

A sánc kutatása során egyéb régészeti jelenségek is napvilágot láttak, bár a kutatóárkokban - méretüknél fogva - telepjelenségek megfigyelésére nem nyílt mód. Az erődítésnek a korabeli településsel való viszonyára két összefüggő felületú ásatásból van adatunk. A "homokgödör" térségében végzett ásatások során a külső vár építését megelőző település objektumait nem sikerült dokumentálni, csak egy olyan, gyakran égett felületeket mutató megtelepedési réteget, amely igen nagy mennyiségú kora középkori leletanyagot, elsősorban kerámiát tartalmazott. A telepjelenségek mellett, részben azok felett a Priwina udvarházán belül található Szúz Mária-

\footnotetext{
9 Cs. Sós 1963, 120-122, Karte 7.

10 Cs. Sós Ágnes ásatási dokumentációja, részleteiben közöletlen; GERGELY 2010.
}

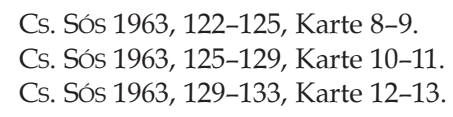



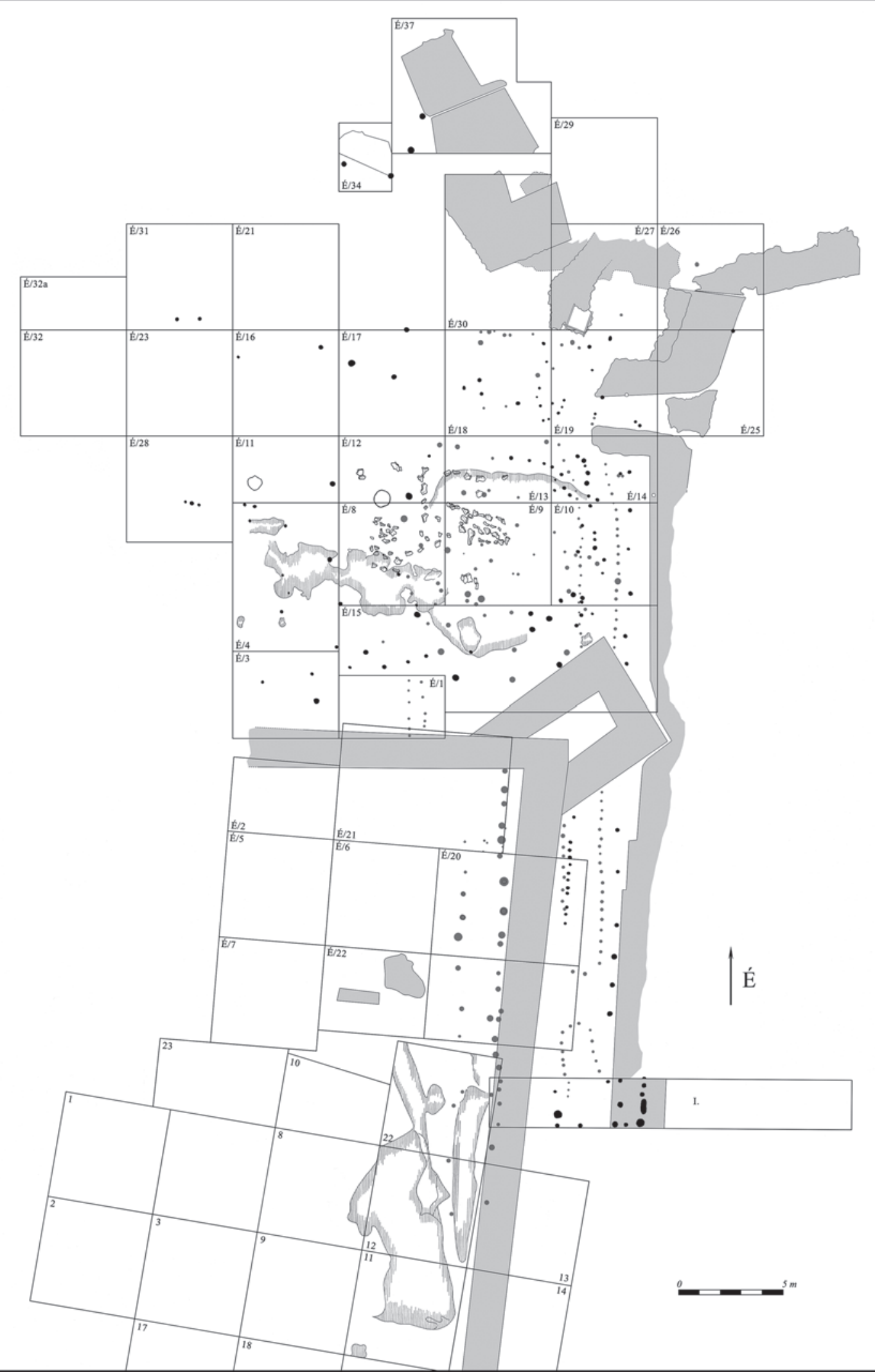

2. kép. Zalavár-Vársziget, délkeleti rész. Fehér Géza ásatásainak (1951-1954) összesítő alaprajza (Cs. Sós 1963 nyomán; rajz: Ösi Sándor). Világosszürke = Árpád-korra keltezett falak; szürke = 9. századi települési objektumok és a paliszád cölöpei; fekete = az Árpád-korra keltezett sánc cölöpei

Abb. 2. Zalavár-Vársziget, südöstlicher Teil. Gesamtplan der Ausgrabungen von Géza Fehér (1951-1954) (nach Cs. Sós 1963; Zeichnung: Sándor Ősi). Hellgrau = in die Árpádenzeit datierte Mauern; grau = Siedlungsobjekte und die Pfosten der Palisade aus dem 9. Jh.; schwarz = Pfosten der in die Árpádenzeit datierten Schanze 


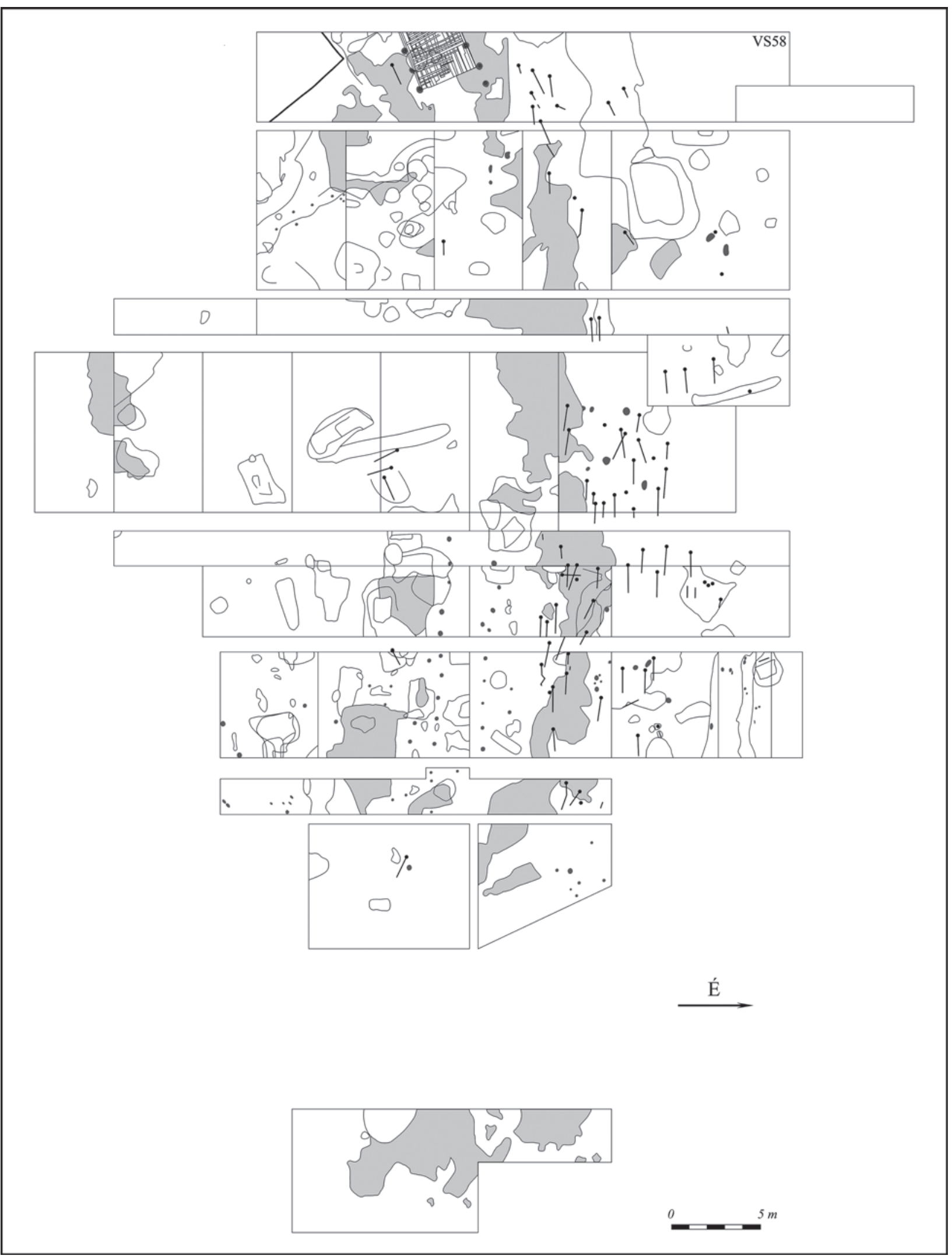

3. kép. Zalavár-Vársziget, északi szigetszél. Cs. Sós Ágnes ásatásainak (1973-1978) összesítő alaprajza (GERGELY 2010 nyomán; rajz: Ősi Sándor). Szürke = az erődítés cölöpei és kőomladéka; fekete = az erődítés közelében feltárt sírok

Abb. 3. Zalavár-Vársziget, nördlicher Inselrand. Gesamtplan der Ausgrabungen von Ágnes Cs. Sós (1973-1978) (nach GERGELY 2010; Zeichnung: Sándor Ősi). Grau = Pfosten und Steinschutt der Befestigung; schwarz = Gräber in der Nähe der Befestigung 
templom körüli temető 9. századi sírjai láttak napvilágot. ${ }^{11}$ Ezzel szemben a Vársziget északi szélén, az erődítés rétegei alatt egy 9. századi települési objektumokkal súrün fedett települési horizontot tárt fel Cs. Sós. Részben ezekbe az objektumokba ásva, részben az e feletti rétegben került elő egy melléklet nélküli sírokból álló temető. A szigetszéli település életét a feltáró, Cs. Sós szerint a 11. századra keltezett várfal zárja. ${ }^{12}$

\section{A sánc értékelése}

Az ásatás vezetője, Fehér Géza 1953-ban az MTA Régészeti Bizottsága számára írott jelentésében pontokba szedve foglalta össze a sánc szerkezetére és keltezésére vonatkozó eredményeket, egyben utalva az összetett rétegviszonyokra:

Tisztáztuk a külső vár vonalát és szerkezetét. [...] Mind a négy metszetünk mindjárt a munka megkezdése után meghozta az eredményt, néhány soros földdel összekötött lapos homokkőfalat találtunk. Hatalmas tartógerendák és cölöpök kötötték le a talaj mozgását.

A kőfal korára vonatkozólag a következőket állapíthatjuk meg:

A, A falhoz tartozó cserepek között egy sem volt, amely 11. század utáni.

$\mathrm{B}, \mathrm{Az}$ 1. metszetben, amely még nincs teljesen feldolgozva, a rakott falban és dólésében csak olyan cserepek kerültek elő, amelyek kora legkésőbb a 11. század eleje.

C, Az 1. metszetben a kőfal legalsó kövei alatt csontváz került elő, amely hozzátartozik a vári temetőhöz, amelyről pedig megállapítottuk, hogy megelőzi Szent István építkezését, különben ezt mutatja a koponya melletti szláv és frank cserép.

D, A 3. és 4. metszetben is kerültek elő sírok, amelyeket azonban nem használhatunk korhatározókként, mert pl. a 3. metszet olyan távol van vári temetőnktől, hogy a benne talált sír nem tartozhat ehhez a temetőhöz, annál is inkább, mert közben van a kápolna körüli temető, amelyról feltettem, hogy akkor népesült be, miután a vári temető megszúnt. Egyelőre pedig nincs alapunk arra, hogy feltegyük, hogy a vári és kápolnai temető összefüggenek. Feltehető természetesen az is, hogy a falak alatt található csontvázaknak van valami különleges jelentőségük.

A 2. és 3. metszetben a falak alá nyúló, súrûn egymás mellé fektetett hosszanti gerendák s néhány keresztgerenda mutatta, hogy a kőfalazást biztosították a süllyedés ellen, ugyanazt a célt szolgálta a fal másik oldalán levő cölöpsor. De döngölt földdel is biztosították a falat. Miután ez a fal csak alépítmény lehet, az a feltevésünk, hogy ez csak alapja a rárakott földfalnak. Az is biztos,

11 Cs. Sós 1963, 38-117. Itt még nem a Szúz Mária-templom temetőjeként szerepel; SzŐKE 2014, 66.

12 Cs. Sós 1974, 70. A periodizáció és a keltezés a feldolgozás során megváltozott: a temető valójában az erődítés megépülte után létesült, keltezését lásd később; GERGELY 2010. hogy a fal alapos vizsgálata azt fogja mutatni, hogy a falazás előtti korban pusztán döngölt földból állott a külső várfal.

Az első metszetben megfigyelhettük, hogy a kőfalat a dőlés ellen cölöpök biztosították. Az 1. metszet világosan mutat egy későbbi állapotot is. Ti. itt a vékony homokkőlapokból álló fal felett igen nagy faldőlés van, amelyben késő középkori anyagot találtunk; e régi várfal fölé a késői középkorban hatalmas kemény kövekkel és téglákkal teleszórt földfalat építettek.

Eddig tehát kétségtelenül megállapítottuk, hogy hol haladt a külső várfal, s milyen a szerkezete, s azt is, hogy ez a külső várfal legkésőbb Szent István korában épült. E fal mindenütt mintegy $1 / 2 \mathrm{~m}$ magas, eredetileg sem lehetett sokkal magasabb, tehát ez nem a fala volt a külső várnak, csak a mozgó talajnak olyan biztosítása, amelyre építették földból stb. a magasabb falakat.

De a falakban talált anyagból megállapíthatunk egyebet is, azt, hogy miután az 1. metszeten kívül sehol sincs későbbi cserép, nem volt átépítve a külső várfal a 11. század után - csak a belső vár mögött, ahol a belső várat használták - esetleg egy kisebb terjedelmú s egyszerúbb szerkezetú külső védelmi vonallal - Turco rajza is ilyenre enged következtetni.

További kutatásaink fogják eldönteni azt, ami valószínú, hogy a sziget szélét biztosító külső várfalat nem Pribina építette-e, eredetileg csak földből, s Szent István kőalapozattal stb. erősítve átépítette. ${ }^{13}$

A jelentés utolsó mondatában megfogalmazott lehetőség már nem vetődik fel a Fehér ásatási eredményeit taglaló monográfiában. Szerzője, Fehér közvetlen munkatársa, Cs. Sós Ágnes az eródítést („,külső várat") az államalapítás utáni emlékek első elemeként tárgyalja. A sánc szerkezetének részletező bemutatása azonban kimaradt a publikációból. A hiányt nem pótolja az egyes cölöpök aprólékos leírása, a vélt konstrukciót sejtető rajzi rekonstrukció és ennek szöveges ismertetése sem. ${ }^{14}$ E szerint a Várszigeten két, nagyjából azonos helyen futó erődítési vonallal számolhatunk: a Vársziget 9. századi erődítése egy kettős cölöpsor által közrefogott, döngölt földet tartalmazó, vesszófonatos szerkezet volt, míg az Árpád-korra datált ún. külső várfal egy cölöpökkel támogatott keresztgerenda-szerkezeten alapuló kőfalazat lehetett. Az értékelést a különböző erődítéstípusok ismert párhuzamai is támogatták: a fonott, cölöpös föld-fa szerkezetú paliszádok analógiáit a 9. századi szláv központokban tárták fel. ${ }^{15} \mathrm{Az}$ ennél összetettebb, kő-faföld szerkezetú erődítés számos emléke maradt

13 Fehér Géza ásatási jelentése az Akadémia Régészeti Bizottsága számára, 1953. Magyar Nemzeti Múzeum Adattár VIII.75/1979.

14 Cs. Sós 1963, 10-14, 23-33, 119-138.

15 Cs. Sós 1963, 32, Abb. 9. 
meg a közép-kelet-európai térségben a 10-12. századból, így a zalavári sánc korai Árpád-korra való keltezése logikusnak túnt. A stratigráfiai összefüggések - 9. századi telepjelenségek és a sánc alatt feltárt „Szzent István kora előtti temetkezések" - mellett az I. sáncátvágásból származó leletanyag is a kora Árpád-kori keltezést valószínúsítette az ásatók számára.

\section{Az értékelés kritikája}

Az 1963-ban német nyelven megjelent publikációban közölt értékelést és az azt kiegészítő rekonstrukciós rajzot Cs. Sós Ágnes 1973-ban szintén német nyelvú monográfiájában változtatás nélkül megismételte. ${ }^{16}$ Ezek a közlések, valamint Gerő László összefoglaló munkája ${ }^{17}$ olyan széles körben terjesztették el a szóban forgó rekonstrukciós rajzokat, hogy azok mélyen bevésődtek a szakmai köztudatba. Ennek köszönhetó, hogy Zalavár említése kapcsán a mai napig léptennyomon ezek a rajzok bukkannak fel, továbbá, hogy mind ez idáig nem jelent meg komoly kritika az erődítés interpretációjával kapcsolatban. A nemzetközi szakirodalom a legutóbbi publikációkig ${ }^{18}$ szintén ezt vette alapul, és nem kérdójelezte meg a 9. századi és az Árpád-kori erődítések értelmezését. A magyar szakmai közvélemény sem fogalmazott meg éles hangú kritikát Cs. Sós értékelésével szemben, bár az utóbbi másfél évtizedben a kérdéssel foglalkozók között egyre határozottabbá vált a meggyőződés az erődítés datálásának tarthatatlanságát illetően. Bóna István kételkedve fogadta az erődítés Árpád-kori keltezését: „Ekkora méretú és ilyen alakú föld-fa vár a korai Árpád-korban nem létezett."19 A Vársziget Árpád-kori erődítéseit Ritoók Ágnes vizsgálta, aki a külső vár 9. század utolsó harmadára való keltezése mellett foglalt állást. ${ }^{20} \mathrm{~A}$ kettős/többszörös cölöpsoros, masszív döngölt földsánccal és elővédfallal ellátott szerkezet párhuzamait a korabeli morva és szláv lelóhelyekben jelölte meg. Mordovin Maxim doktori diszszertációjában az Árpád-kori sáncok között már nem is vette számba Zalavár külső erődítését. ${ }^{21}$ Szőke Béla Miklós legutóbbi munkájában történeti keretek közé helyezte az erődítés építését; kivitelezését a 890-es évekre valószínúsítette, és

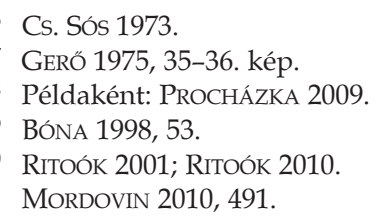

Braszlav tevékenységéhez kötötte. ${ }^{22}$ Kritikai megjegyzéssel pedig a kapuszerkezettel kapcsolatos elképzeléseket illette: a sziget ezen részén nyitott kapukat, a paliszád kapuját és a külső vár kapuzatát is indokolatlannak tartja Mosaburg régészetileg feltérképezett agglomerációjának ismeretében. ${ }^{23}$

\section{A sánc szerkezetének újraértékelése}

Az erődítés kutatásának eredeti dokumentumait és a sáncátvágásokból származó leletanyagot öszszevetve egyértelmúvé vált, hogy az ásatók külső várfallal kapcsolatos konklúziója az I. számú átvágás alapján született meg. Fehér és Cs. Sós ezt vették alapul az értékeléskor, annak ellenére, hogy a II., III. és IV. számú kutatóárkok a Vársziget olyan pontjain húzódnak, ahol nem kellett számolni a súrú beépítettség és a későbbi korszakok építkezései okozta bolygatásokkal. Metszeteik világosabb képet nyújtanak a sáncról, és a belőlük előkerült leletanyag is jóval egységesebb. ${ }^{24}$

A sánc szerkezetének felülvizsgálatára annak a feltárásnak a feldolgozása kínál alkalmat, amelyet Cs. Sós Ágnes végzett a mai ZalaszabarZalavár közötti múúttól északra, a Vársziget északkeleti szélén. Tíz éven át több mint 50 méter hosszú szakaszon tárta fel a szigetet övező erődítést és az alatta húzódó szigetszéli településrészt. ${ }^{25} \mathrm{Az}$ 1950-es években nyitott II., III., IV. sáncátvágások, valamint az újabb, az úttól északra feltárt VS41-VS103 kutatóárkok dokumentációi és leletanyaga alapján az alábbi következtetésekre jutottam.

\section{Szerkezeti jellegzetességek}

\section{Cölöpszerkezet}

Cs. Sós Ágnes interpretációja szerint a szigetet körbevevő külső erődítésnek legalább két fázisa van: ${ }^{26}$ közvetlenül egymás mellett, párhuzamosan fut a 9. századi egyszerú sövényfonásos (?), két cölöpsor közé döngölt, fa-föld szerkezetú

22 SZŐKE 2015, 36.

23 SZŐKE 2011, 306.

24 A II., III. és IV. sáncátvágások leírását lásd: Cs. Sós 1963, 122-138.

25 Gergely 2010.

26 A külső várfal átvágása során bizonyos cölöplyukakat 9., másokat 11. századinak, további jelenségeket kora újkorinak tartottak, amelyek sorából kirajzolódni véltek egy nagyjából azonos helyen futó, három különböző korú és eltérő szerkezetú, a Vársziget egészét körülvevő erődítést: Cs. Sós 1963, 10-13, Abb. 4. 


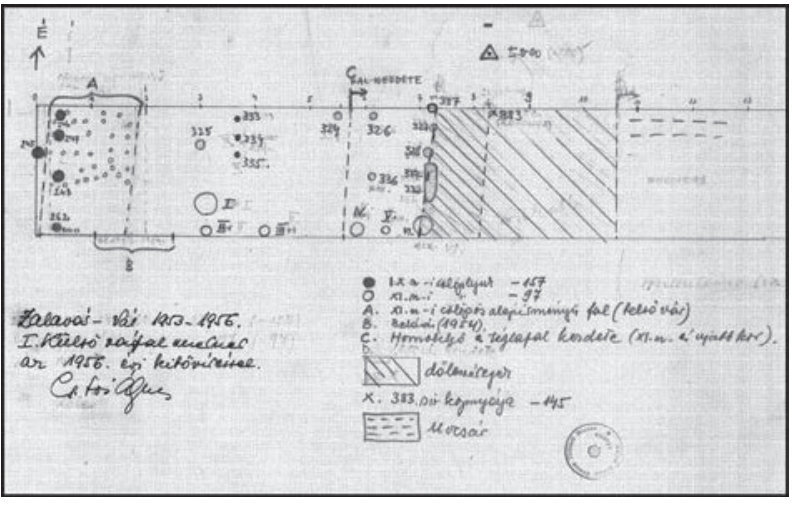

4. kép. Zalavár-Vársziget, az I. sáncátvágásban feltárt oszlopok (Cs. Sós Ágnes rajza)

Abb. 4. Zalavár-Vársziget, die Pfosten des I. Burgwallschnittes (Zeichnung: Ágnes Cs. Sós)

paliszád és a komolyabb szerkezetú, kővel köpenyezett gerendaszerkezetes, döngölt földbázisú Árpád-kori sánc. A leírásokban ezt a két erődítést egymástól élesen elválasztva tárgyalja, és nem szól a védmúvek kapcsolatáról, egymáshoz való viszonyáról, pedig a metszetek és rekonstrukciók azt sugallhatják, hogy a 9. századi erődítést felhasználva épült ki az Árpád-kori sánc. ${ }^{27}$ Véleményem szerint azonban a két külön periódusba sorolt és a rajzos rekonstrukciókon is külön megjelenített szerkezet valójában egyetlen és minden valószínúség szerint egyidejú erődítés részét képezte. Méghozzá oly módon, hogy a (9. századra keltezett) cölöpös szerkezetú, döngölt földdel kitöltött sánc alkotta az erődítés magját, ez elé pedig kívülról egy szárazon rakott kő köpenyfalazat/lábazat került, amelynek stabilitását a kisebb cölöpök és a vízszintesen fekvő gerendák biztosították. ${ }^{28}$

Az erődítési jelenségek két korszakra való szétválasztását részben a cölöpök mereven alkalmazott formai osztályozása, részben pedig a kontinuusnak feltételezett településtörténet magyarázza: Cs. Sós Ágnes különböző korszakokba sorolta, és rajzos táblákon mutatta be az eltéró formájú, méretú és kialakítású cölöpöket. ${ }^{29}$ De már az összesítő rajzok alapján felmerült a gyanú, hogy a korszakolás nem állja meg a helyét, hiszen ha a 9. századi és Árpád-kori jelenségeket összesítő térképeket összevetjük, jól látszik, hogy a más és más korszakokba sorolt cölöpök többsége egy rendszerhez tartozik (lásd 2. kép). Ráadásul az I. metszetben megtalált oszlopok

27 Erre egyébként másutt is van példa: lásd Břeclav-Pohansko (DRESLER 2011, 75).

28 Cs. Sós 1963, 23-33, 119-138, Abb. 9 és Abb. 48

29 Cs. Sós 1963, Abb. 7-8.
(I-VI.) a metszetrajzokon az Árpád-kori erődítés részét képezik (4. kép). Az alaprajzokon azonban ezek vonalában, a sor folytatásában nem az Árpád-kori cölöpök vannak feltüntetve, hanem az állítólagos 9. századi sövényfonatos rendszer oszlophelyei. A 9. századra keltezett és külön jelenségként számon tartott paliszádhoz tartozó cölöphelyek tehát sajátos módon pontosan végigkísérik a Szent István-korinak ítélt külső várfalat (annak saját oszlopaival). A kettős cölöpsor alkotta rendszer nemcsak hogy követi a sánc vonalát, de szembetúnő módon éppen a Vársziget belseje felé nyíló déli kapuszárny belső síkjáig terjed. A sánc déli kapuszárnyának metszete nyugat felé, a Vársziget belseje felé lépcsős kialakítást mutat, amelyról ebben az esetben felvethetô, hogy a mellette lévő, lépcsős felépítésû sáncszerkezetet követi. ${ }^{30}$

A cölöpös védelmi vonal külső várfaltól különálló, független fennállására mindössze egyetlen adat utalhat: a paliszád vonalát Cs. Sós feltételezése szerint egy ún. Levý Hradec-típusú kapu szakította meg. Csakhogy a közölt metszetrajz elárulja, hogy a hiányzó szakasz teljes feltárása nem történt meg. ${ }^{31} \mathrm{Az}$ oszlopsort átvágták, és annak vonalából hiányoztak a sor folytatását jelentő cölöpök, ezért feltételeztek itt egy kaput. Ugyanakkor az összesített alaprajz szerint az Árpád-koriként meghatározott cölöpök folytatják a sort. A két konstrukció (9. századi és Ârpádkori) összetartozását jelzik a metszetben a levert cölöpök feletti rétegben a sáncra merőlegesen fektetett gerendák fészkei, amelyek ugyanarra a szerkezetre utalnak, mint amelyet később a sziget más területén, a várfalátvágások során mindenütt tapasztaltak. Az pedig, hogy a Várszigetet övező falon nyitott kapu belső oldalán, attól 3 méter távolságra egy 20 méter hosszúságú, más kialakítású oszlopokból álló, sövényfonatos védfalat emeljenek, meglehetősen valószínútlennek túnik.

$\mathrm{Az}$ átvágások metszetrajzai alapján még egyértelmúbb a két különálló szerkezetnek minósített jelenségek összetartozása: a 9. századiként meghatározott cölöpök és az Árpád-kori sánc szilárdítását biztosító cölöpök ugyanabból a szürke agyagos rétegből indulnak ki. A felettük húzódó, döngölt agyagos rétegek és a vízszintes gerendák szintén összekötik a sánc két szakaszát: a sánc bázisát adó cölöpös-gerendás, agyaggal feltöltött részt és az elé rakott, vékony cölöpökkel szilárdított kőfalazatot (5. kép). Az egyes számú átvágásról készült alap- és metszetrajzon ezt a szerző is egyként értékeli, az összesítő rajzokon azonban már két különálló rendszert sugall.

30 Cs. Sós 1963, Abb. 49.

31 Cs. Sós 1963, Abb. 5. 


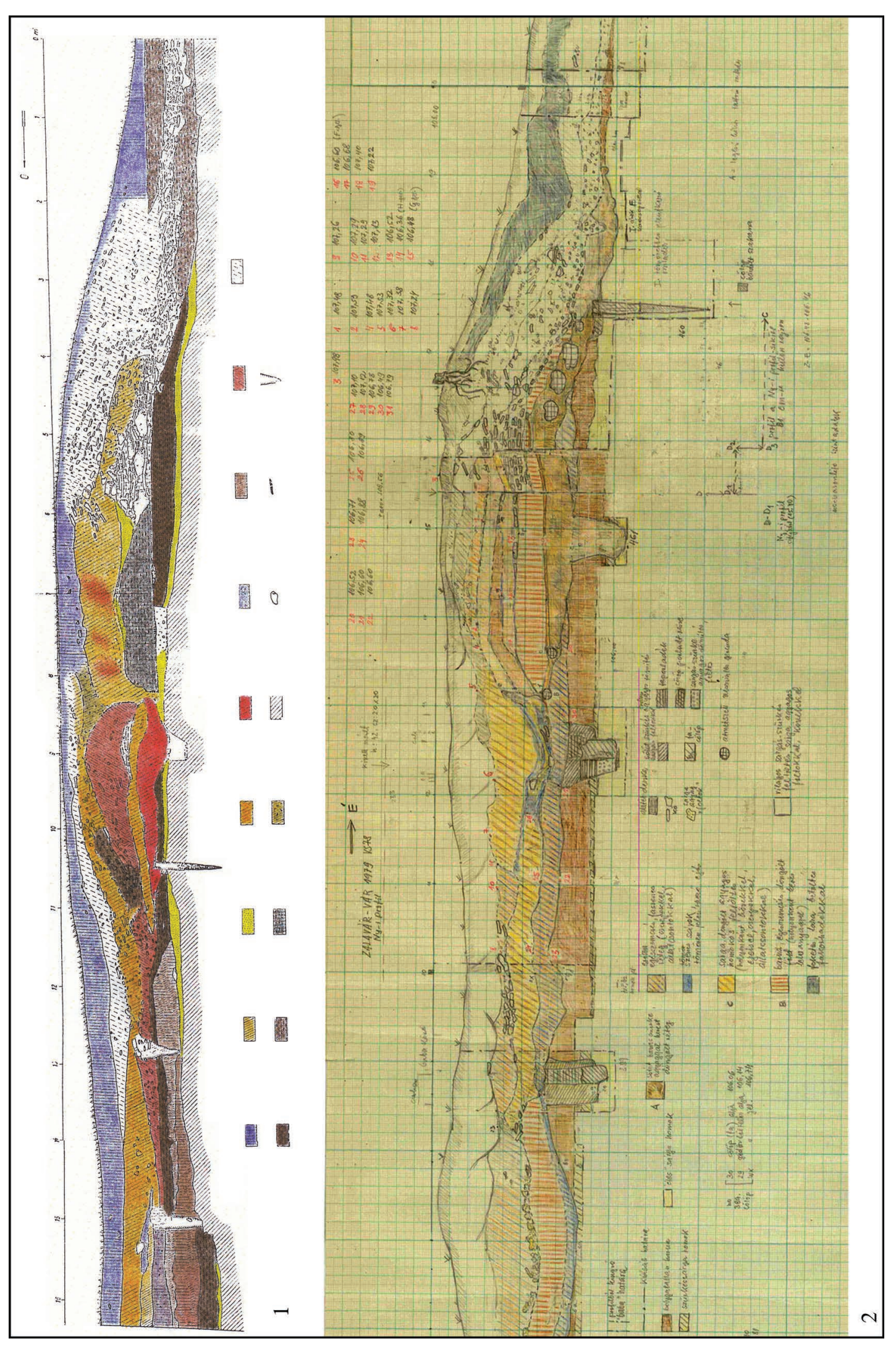

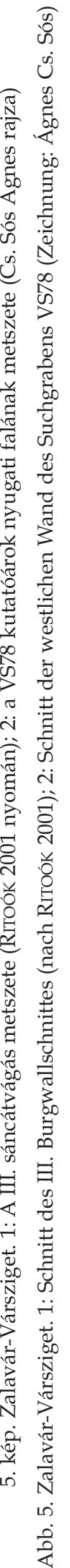


A cölöpös sáncszakaszon belül a két oszlopsor egymástól mért maximális távolsága 4-6 méter (a „paliszádhoz” és a „kőfalhoz” tartozók együttesen). Az északi szigetszélen végzett feltárás eredményei megerósítették a korábbi megfigyeléseket és újabb adatokkal egészítették ki azokat. A szélesen elterült kőomladék belső oldalán szabályszerúen két párhuzamos cölöpsort lehetett megfigyelni, amely jelenség erősen emlékeztet a Karoling-koriként meghatározott paliszádra a sziget déli részén. Ennek vonala sem követhetó végig, egy kb. 15 méteres szakaszon megszakad. A kettős cölöpsort belülről itt is kisebb cölöp- vagy karólyukak kísérik, látszólag „rendszerbe nem illö módon”.

\section{Gerendaszerkezet}

Mivel a Fehér Géza és Cs. Sós Ágnes által feltárt I. sáncátvágás kutatóárkában nem találták gerendaszerkezet nyomát, ennek elemzése sem kapott hangsúlyt a feldolgozás során. ${ }^{32} \mathrm{~A}$ további átvágások alkalmával viszont szinte minden esetben megfigyelték és alaprajzban rögzítették a gerendaszerkezetet. Az ezekben találtakhoz hasonló szerkezeti megoldásokat tapasztalt Cs. Sós Ágnes az 1970-es években megásott északi szigetszélen is (lásd 3. kép). ${ }^{33} \mathrm{~A}$ II. és III. átvágás metszeteihez hasonlóan itt is sikerült megfigyelni a sánc magját képező kettős cölöpsor között, a szerkezet stabilitását biztosító függőleges oszlophelyek mellett a vízszintes gerendázatot. A súrún (északi szakasz) vagy ritkásabban (II. és III. átvágás metszete) egymás mellé, a fal irányára általában merőlegesen fektetett, négyszögletesre bárdolt gerendák második rétegét egy ezekre merőlegesen elhelyezett gerenda-, rönk- vagy deszkasor alkotta, szabályos rost- vagy rácsszerkezetben. A gerendák a cölöpök jelentkezési szintjén, a mocsári földön, illetve szürke agyagos rétegen, egymás fölött legfeljebb két rétegben feküdtek, maximum 30-40 cm-es, földdel elegyes „réteget” alkotva. Az északi szigetszéli szakaszon a sánc irányára kb. 45 fokos szöget bezáróan, míg máshol szabályosan, a fal irányára merőlegesen helyezték el a gerendarácsozatot. A gerendaalapozások kiterjedésére csak az északkeleti területről

32 Ugyanakkor nyilvánvalóan ezen a szakaszon sem hiányzott a gerendázat, hiszen a 9. századi cölöprendszer hosszanti metszetéről készült rajzon kivehető a cölöpök felett fekvő, a falra merőlegesen elhelyezett gerendák sora: Cs. Sós 1963, Abb. 5.

33 Cs. Sós Ágnes ásatási dokumentációja alapján: GERGELY 2010. van adatunk. ${ }^{34}$ Az 1975-1978-as ásatások során egy kb. 3,5×4 méteres, sürú rácsozattal fedett felületet tártak fel, majd ennek folytatásában, a fal irányával megegyezően a fal belső oldalán, egy rétegben, súrún egymás mellett, párhuzamosan húzódó gerendákat figyeltek meg. Abból, hogy a mintegy 50 méteren feltárt eródítésszakaszon mindössze 5-10 méteren találták meg az alsó gerendázat nyomát, arra következtethetünk, hogy a sánc vonalán nem mindenütt alkalmazták ezt a szerkezeti elemet.

\section{Kőfalmaradványok}

Teljes, álló kőfalmaradvány a Vársziget egyetlen sáncátvágásában sem volt. A II. átvágás metszetén Vargha László rajzán vehető ki a sánc külső oldalán in situ kőfal maradványa. A szárazon rakott fal $60 \mathrm{~cm}$ magas és mintegy 1,2-2 méter széles, ${ }^{35}$ lapos, szabálytalan alakú, páhoki homokkőből épült. ${ }^{36} \mathrm{~A}$ falazat stabilitását a megfigyelések szerint a fal alá nyúló gerendák és a metszetben megfogott, kisebb átmérójú cölöpök/oszlopok biztosították. A falalapozás, a lábazat a fal szilárdságát biztosítva szélesebb alapra épült; a felmenő részek szélessége ennél jóval kisebb lehetett.

A külső köpenyfal magasságára nincs adatunk. Az eredeti helyzetben maradt kőfal rétegei felett talált nagy mennyiségú kő és kőomladék azonban arra utal, hogy az egykori falat masszívra építették. Nem csak a kapunyílásról készült fotók, de a rajzok is tömör kőfalak csonkjairól árulkodnak. ${ }^{37}$

A legtöbb esetben azonban már csak a kőfalnak az egykori sánc környezetében nagy felületeken szétterülő omladékát lehetett dokumentálni - akár a fal mindkét oldalán. Ez lehet az intenzív földmunka, talajmúvelés következménye, de azt sem lehet kizárni, hogy a földsánc belsó oldalára is húztak egy keskeny kóköpenyt. A fal mindkét oldalán szétterülő kőomladékot elsősorban az északi szigetszélen lehetett megfigyelni (lásd 3. kép), de erre utalhat a kapuszárny belsó metszetén az egy-egy kőlappal fedett, lépcsős kialakítás is a sziget délkeleti szegletében lévő kapu esetében. ${ }^{38}$

34 A sáncátvágási kutatóárkok méretéból adódóan a korai években nem lehetett információt nyerni a gerendakonstrukció méretéről.

35 Cs. Sós 1963, Karte 9.

36 Cs. Sós Ágnes leírása szerint a falak közeit föld töltötte ki: Cs. Sós 1963, 121.

37 Cs. Sós 1963, Taf. XXXV-XXXVIII, valamint László Gyula helyszínen készített rajzai.

38 Cs. Sós 1963, Abb. 49. 


\section{Egyéb szerkezeti elemek}

Az Árpád-kori erődítésről készített rajzi rekonstrukción a külső kőfal előtt egy sövényfonásos palánk is kivehető. Ennek nyomait Vargha László figyelte meg a II. sáncátvágás során. A külső sövényfonást apró karók jelezték a fal előtti rézsúben. Funkciója nyilvánvalóan a fal megközelítésének megnehezítése, illetve a föld csúszásának megakadályozása és a fal mocsár elleni védelme volt. ${ }^{39} \mathrm{Az}$ északi szigetszélen a sánc vonalától távolabb Cs. Sós Ágnes nagy, összefüggő felületen, rendszertelenül, nagy tömegben dokumentált apró karó-/cölöplyukakat, amelyek véleménye szerint a part védelmét szolgálták. ${ }^{40}$

A Vársziget földrajzi környezete nem tette szükségessé a korabeli erődítési rendszereknél megfigyelhető, erődítésen kívüli külső védelmi vonalat, szerkezeti elemet, erődítési árkot, az áthatolhatatlan mocsár ugyanis kellő védelmet biztosíthatott. Újdonságként értékelhetó a szabálytalan körvonalakkal jelentkező - és nem is mindenütt rögzített - árok megjelenése az északi szakaszon. A várfalat kívülról és/vagy belülről helyenként 3 méter szélességben kísérő, süppedék jellegú árok nem a védelmet szolgálta, inkább a földsánc emeléséhez szükséges föld kitermelésekor keletkezett. ${ }^{41}$

\section{Településszerkezeti összefüggések}

\section{Települési objektumok}

A Vársziget déli nyúlványán feltárt jelenségekből kiindulva bőséges adatok állnak rendelkezésünkre a településszerkezet, a stratigráfia tanulmányozására a sánc építését megelőző, majd az azt követő időszakból. Elsőként az összesítő alaprajz vet fel kétségeket az egymáshoz meglehetősen közel futó falak egyidejúségére vonatkozóan. Az egyik legerősebb érv a külső sánc 11. századi keltezése ellen az Árpád-kori monostor 11-12. század fordulóján emelt körítőfalához („,belső vár”) való közelség: a két konstrukció között három méter a távolság. A monostor körítőfalának a külső várfal vonalába bevágó saroktornya szintén cáfolja a falak, illetve a létesítmények egyidejú használatát. ${ }^{42}$

\footnotetext{
39 Cs. Sós 1963, 135.

40 Cs. Sós Ágnes ásatási dokumentációjában ennek leírásakor Adriaan von Müller látogatására hivatkozik, aki BerlinSpandau várának feltárása során hasonló jelenségeket figyelt meg: MÜLLER-MÜLler-MuČI 1983, 34, Abb. 8-10.

41 Vö. Cs. Sós 1963, 136.

42 RitoóK 2010, 46-55; RITOÓK 2014, 294.
}

A külső sáncon kívül a Várszigetnek további védelmi, illetve határoló rendszereit ismerjük. Ezek közül még kettőról kell röviden szót ejteni a külső várfallal való kapcsolatuk miatt. Az L alakú Vársziget délre nyúló szárát egy K-Ny-i irányú, nagyméretú árok, továbbá feltehetóen az ahhoz tartozó sánc és palánkja választották el a sziget többi részétől. Mai tudásunk szerint e mögött sejthető Priwina udvarháza. ${ }^{43} \mathrm{~A}$ nagyméretú árok irányát tekintve éppen a külső eródítés kapujának nyílásába torkollna. A modern ásatások nem érték el ezt a szakaszt, de Szőke Béla Miklós a nyílás nagyméretú kőfalait - a kapu funkciót megkérdőjelezve - az árok partjainak mocsárral szembeni védelmeként értékelte. ${ }^{44} \mathrm{Az}$ 1950-es évek ásatásainak szintadatai, megfigyelései nem szólnak árokszerú bemélyedésról, ezért elképzelhetőnek tartom, hogy a nagyméretú árok (részleges?) betemetése után, e felett emelték az erődítés kapuját.

A Karoling-korban egyszerú palánkok határolták a Vársziget egyes települési egységeit. A sziget középsó részét körülölelő (?) palánk keleti ívét Cs. Sós Ágnes az 1980-as években tárta fel. A palánk által körbevett területet utolsó munkájában a sziget központjának, "akropoliszának” tartotta, és ide lokalizálta Priwina erődített udvarházát. ${ }^{45}$ Ezt a lehetőséget az 1994 óta zajló összefüggő, nagy felületre kiterjedő kutatások elvetették. ${ }^{46} \mathrm{~A}$ Hadrianus-zarándoktemplom funkciójának és jelentőségének meghatározása után sokkal valószínúbb, hogy a palánk a templom körzetének jogi különállását, immunitását jelölte és védelmezte. ${ }^{47}$ Bár a palánk vonala egybevág a déli szigetszakaszon feltárt, 9. századra keltezett paliszáddal (lásd 1. kép), összetartozásukat a Várszigetet kettévágó nagyméretú árok és szerkezeti eltéréseik kizárják. A Várszigetet körbevevő külső erődítés és a belső palánk(ok) viszonyának tisztázására a sziget északi peremén húzott kutatóárkok jelenségeinek aprólékos feldolgozása teremt majd lehetőséget. Annyi bizonyos, hogy két különálló és eltérő funkciójú jelenségről van szó, amelyek a Karoling-kori Vársziget életének két különböző korszakában létesültek: a központ kiépülésének idején, illetve a század végén (lásd 1. kép; vö. a Függelék adatait).

A külső erődítés és a korabeli település viszonyára vonatkozóan két helyról van információnk. A teljes déli feltárási területen, az I. sáncát-

\footnotetext{
43 SZÖKE 2014, 55; SZÖKE 2011, 310-317.

44 SZŐKE 2011, 310.

45 Cs. Sós 1994, 86-87.

46 Lásd SZŐKE 2014; SZŐKE 2011.

47 SZŐKE 2014, 101.
} 
vágás közelében nagy mennyiségben szétterült leletanyag, szerves anyag és égett felületek ellenére alig sikerült települési objektumokat megfigyelni. A megszámlálhatatlan, nem eródítéshez tartozó cölöplyuk nem rajzol ki egységes konstrukciót, de felmerült egy nagyméretú felszíni építmény, a környező sírok alapján esetlegesen egy fatemplom lehetősége is. ${ }^{48} \mathrm{E}$ réteg és a sánc közvetlen kapcsolatára vonatkozóan nem áll rendelkezésünkre adat, a leletanyag alapján azonban az égéses településréteg egyértelmúen a település 9. század közepi fázisához köthető. Ezt támasztja alá, hogy a leégett települési jelenségbe még a 9. században sírokat ástak. ${ }^{49} \mathrm{Az}$ északi szigetszélen azonban egy periferikus helyzetú, jól körülhatárolható településrészlet terült el. A települési objektumok között félig földbe mélyített és földfelszíni házak, valamint különféle rendeltetésú gödrök fordultak elő. Az erődítéshez tartozó cölöprendszer és kőomladék ezek felett feküdt, részben ezt a települési fázist bolygatta meg. ${ }^{50}$ A település kora az objektumokban és a szelvények szórvány anyagában előkerült kerámia alapján a 9. századra tehetó. A biztosan Árpád-kori darabok alig egy százalékát tették ki a leletanyagnak. ${ }^{51}$

\section{Temetkezések}

Az eródítés 11. századi/Szent István-kori keltezését - többek között - arra alapozták, hogy az I. sáncátvágásban a "külső fal” alatt egy sír maradványára bukkantak (383. sír koponyája), amelyet helyzete és a mellette talált cserepek alapján a 9. századra kelteztek. A III. és IV. átvágás során további két-két csontvázat találtak. A sáncot átvágó kutatóárkok egymástól való távolsága miatt a sírok nem tartozhattak egyetlen templom körüli temetőhöz, hovatartozásuk kérdését nem lehetett eldönteni.

Az északi szigetszélen Cs. Sós mintegy százhúsz sírt tárt fel. Az ugyanitt kiásott településrészletet a 9-10. századra datálta, és mivel a korábbi falátvágások alapján a külső várfalat az Árpád-korra keltezte, a sírokat e két időszak közé helyezte, templom körüli temetőt feltételezve. ${ }^{52}$

A csontvázas, szegényes melléklettel bíró vagy melléklet nélküli sírok általános jellemzője, hogy szinte minden esetben kőréteg alól vagy kövek közül kerültek napvilágra. Ez azonban nem jelentette azt, hogy a sírok a fal alatt feküdtek volna, és

\footnotetext{
48 Cs. Sós 1973, 112-114.

49 Cs. Sós 1973, 114.

50 Gergely 2010.

51 Gergely 2010, 52.

52 Cs. Sós 1974, 69-70.
}

egyetlen esetben sem lehetett megfigyelni a fal építéséhez köthetó sírbolygatást. A leírások, a rajzok és/vagy fotók alapján egyértelmúen igazolható, hogy a sírokat csak a fal köveinek omladékrétege fedte, azaz a fal építésénél késóbbiek. Az összesító térképen jól látható, hogy a sírok többsége a külső fal vonalát követi, tehát a temetó hosszanti irányban, a sánc mentén terjeszkedik. A sírok tájolása szintén a sánc irányához igazodik, és a fal mentén alkotnak néhány sírból álló csoportokat. Ez azt jelenti, hogy a sírok megásásakor a falnak állnia kellett, vagyis a temetőrészlet a fal felépítését követő időszakban volt használatban. Ezt támasztják alá az északi szigetszélen a sánc mentén futó árokszakaszba temetett sírok is, amelyek szuperpozíciójuk révén döntően meghatározzák a jelenségek egymáshoz való viszonyát.

A teleprészlet értékelésekor kezdetben csak arra figyeltem fel, hogy a sírok többségét az erődítésen kívül, annak vonala mentén, ahhoz igazítva találjuk. Ennek alapján egy sajátos, az erődítéshez kötődő temetkezési szokást véltem felfedezni a jelenség mögött. Néhány egészen más pozíciójú sírról is szót kell azonban ejteni, amelyek árnyalják a képet: Méri István a III. metszetben, a gerendakonstrukció alatt egy 9. századi sírt tárt fel. Ebben az esetben biztosan egy a fal emelését megelőző jelenségről van szó. Az északkeleti szigetszélen dokumentált sírok egy része az erődítés belső (déli) oldalán, települési objektumokba ásva került elő. ${ }^{53}$ Egy másik csoportjuk pedig olyan közel fekszik a sánc bázisát adó cölöpös szerkezethez, hogy elképzelhető, ezeket a sírokat még a kő-fa-föld szerkezetú erődítés megépítését megelőzően ásták meg. ${ }^{54}$ A szomszédos Kövecses-szigeten feltárt 9. századi szolgálónépi, nyílt település peremén, a természetes szigetszélen, egy bizonyos tengerszint feletti magassági vonalat ",követve" települési objektumokban, illetve a település szélén temették el a halottakat kisebb csoportokban..$^{55}$

Mindezek alapján a 9. század végén ${ }^{56}$ és/vagy a 10. század folyamán a Karoling-kultúrájú

53 Hasonló szokást, települési objektumba való temetést a Vársziget más területein is megfigyeltek, például a kápolna területén: Rітоóк 2005, 175.

54 Ha valóban létezik a sáncnak egy korábbi periódusa, akkor ezek a sírok esetlegesen ehhez a fázishoz tartoznának, vagyis az eredeti, kő nélküli sánc tövében való temetkezés nyomai lennének.

55 Cs. Sós 1984.

56 A 9. század végi datálás mellett szólhat az egyetlen, ténylegesen az erődítés alatt feltárt gyermeksír egyszerú, sárga-kék szegmentált gyöngyökből álló gyöngysorral (Cs. Sós 1963, 129), valamint néhány kövecsesi sír melléklettel, köztük millefiori gyöngyökkel (Cs. Sós 1984, T. I). Ezeken kívül nincsen semmilyen fogódzónk arra nézve, hogy a Vársziget 
Mosaburg térségében a keresztény hithez (már és még) nem kötődő, pogány lakosság ezekben a nem templom körüli, hanem a települések elhagyott részén és/vagy a szigetek szélén nyitott sírokban nyugodott. Feltehetóen egy korábbi, de a 10. századtól újraéledő hagyományt elevenítettek fel - az elhagyott településeken, erdős, ligetes területeken történő temetkezés gyakorlatát -, amikor az erődítéshez kezdték igazítani sírjaikat, majd a fal pusztulása után még mindig annak közelébe, esetleg kövei közé ásták el halottaikat. ${ }^{57}$

Az erődítés külső falához való temetkezés nem korlátozódik Zalavár térségére. A legközelebbi párhuzam látszólag Keszthely-Fenékpuszta déli erődfal előtti temetője. ${ }^{58}$ Itt azonban nem az erődítéshez való közelség, sokkal inkább az erődítésból kivezető úthoz való viszony játszotta a döntő szerepet, amikor a 9. század közepe táján egy mellékletekben gazdag, pogány rítusú temetốt nyitottak az erőd tövében, a déli kapu két oldalán. ${ }^{59} \mathrm{Az}$ újabb kutatások sorra a várszigetihez hasonló, 9. század végi, 10. század eleji sírokat, sírmezőket hoztak napvilágra Staré Městón, ${ }^{60}$ Mikulčicén ${ }^{61}$ és Nyitrán, ${ }^{62}$ továbbáPobedényben. ${ }^{63}$ Břeclav-Pohansko legutóbbi ásatásain a sánc közelében feltárt sírok esetében is az eródítéshez való igazítást lehetett megfigyelni. ${ }^{64}$ A településeken belüli, illetve egyszerú köznépi temetőkbe való temetkezés szokása a cseh és morva területeken egészen a 12. századig gyakorlatban volt, még akkor is, amikor a településen már keresztény templom állt. ${ }^{65}$ Renáta Přichystalová a

szélén a települési objektumokban fekvő - nem az erődítéshez igazított - sírokat a sánc megépülése előtt vagy után ásták. Egyik lehetőség sem zárható ki. A 9. század végi keltezés ellen szól ugyanakkor, hogy az említett néhány leletnek nincsen pontos datáló értéke; 10. század eleji szórványos előfordulásuk is lehetséges. A legnyomósabb érvet azonban a történeti források szolgáltatják: 896-ban Arnulf Braszlavra bízza Mosaburgot, a Dunántúl legjelentősebb keresztény települését, ahol ekkor még nem képzelhető el a pogány temetkezési szokások újjáéledése: lásd SzőKE 2011, 158, 289; SZŐKE 2014, 109, 119.

57 A régi szokásokhoz való visszatérésre utal a pogány mellékletadás újbóli megjelenése Zalaváron a honfoglalás után: SZŐKE 2005, 26.

58 MÜlLER 2010.

59 A párhuzam látszólagos voltára Szőke Béla Miklós hívta fel a figyelmemet, amiért köszönettel tartozom. Ld. még: SZÖKE 2010.

60 GALUŠKa 1998, 345.

61 PROCHÁZKA 1998, 366

62 BEDNÁR 1998, 375.

63 HenNing-RutTKay 2011, 268.

64 Dresler 2011, 71; PřichYstalová 2011, Abb. 5.a-d

65 A keresztény vallás és a pogány hiedelmek egymás mellett élésének bizonyítékait, a régészeti adatok mellett a törvényi rendelkezéseket, tiltásokat Peter Sommer foglalta össze: SOMMER 2000, 176. A vallási elképzelésekben és ennek nyo-
Břeclav-Pohanskón feltárt temetkezéseket vette sorra, köztük a „rendellenes” elhelyezkedésúeket. A kapuknál, a sánc fala mellett és az elővárak különböző településrészletein majdnem annyi elszórt vagy kisebb csoportokba rendeződött 9. századi temetkezést tártak fel, mint amennyi a templom körüli temetőből ismert. ${ }^{66}$

\section{A leletanyag}

Fehér Géza a sáncátvágásokból elókerült leletanyagnak is figyelmet szentelt. A sánc keltezése során ugyan nem a kerámia volt a leginkább meghatározó, de Fehér felismerte és - a sánc Árpád-kori keltezése ellenére is - hangsúlyozta, hogy kizárólag az I. számú sáncátvágásból került eló Árpád-kori kerámia. Az itt tapasztalt rétegviszonyok és a Vársziget periodizációjának bemutatására az átvágásból származó kerámiát fényképes kronológiai táblába rendezte. ${ }^{67}$ A keltezést ennek eredményei alapján (is) úgy pontosította, hogy a fal megépítésére legkésőbb Szent István korában kerülhetett sor.

A sáncátvágások leleteit újra elemezve első pillantásra is szembetúnő a II., III. és IV. kutatóárkok, valamint a teljes északi szigetszélról származó leletanyag egyöntetúsége: ezekben ugyanis szinte kizárólag 9. századi kerámia látott napvilágot. Biztosan Ârpád-korinak tartható kerámia nem került elő, vagy nagyon kis mennyiségben, és csak a felsóbb rétegekból. A leltárkönyvi bejegyzések alapján minden leletet pontos mélységadattal csomagoltak el, ami - különösen a hosszú időn át használatban lévő területeken, így az I. sáncátvágás anyagában - a relatív kerámiakronológiai sor felállításával kecsegtetett. Valójában azonban kutatóárkon belüli helymegjelölés híján a leletanyagnak csak kis részét lehetett konkrét helyhez, illetve réteghez kötni, így a sánc keltezésére használni. A tervezett időrendi sor felállítására nem nyílt mód, mindössze a

mán a temetkezési szokásokban megfigyelhető változások a temetők különféle típusait hozták létre. A hamvasztásos temetkezésról a csontvázasra való áttérés során a települések szélén sírcsoportokból álló temetők, "Gruppengräberfeld" típusú temetők jöttek létre, majd a 10. század folyamán a kereszténység hatására ezek folyamatosan soros temetőkké alakultak át. Ezek a temetők a cseh területeken egészen a 12. század végéig, a 13. század első feléig használatban voltak, mígnem teljesen kiszorították őket a templom körüli temetők.

66 Přichystalová 2011, egymáshoz viszonyított arányuk: Tab. 1. Korábban a településeken belüli temetkezésekről: UNGER 2004.

67 Cs. Sós 1963, Taf. LXXIII. 


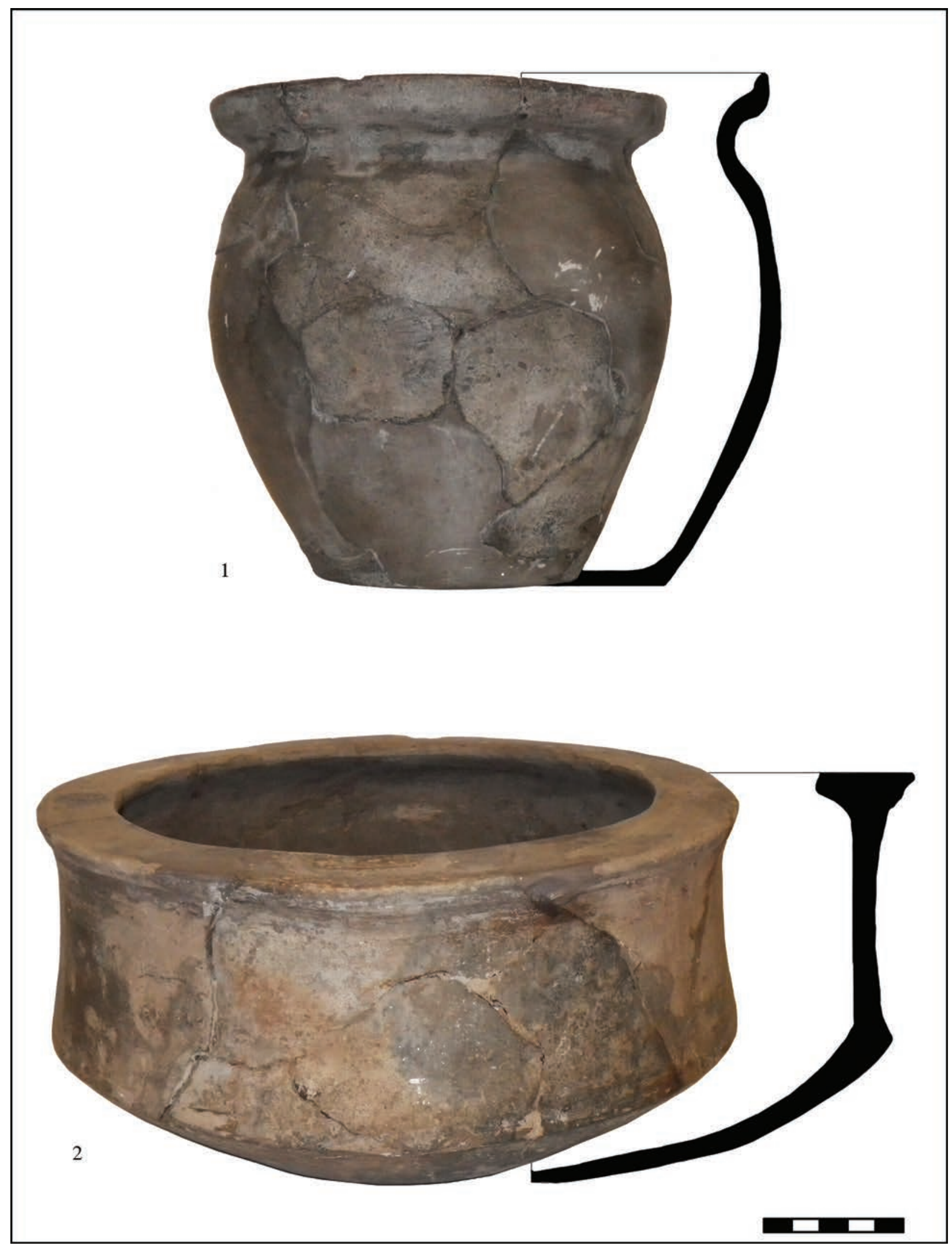

6. kép. Zalavár-Vársziget, kerámia az I. számú sáncátvágásból. 1: „M: 135 cm”; 2: „M: 210 cm” Abb. 6. Zalavár-Vársziget, Keramik aus dem I. Burgwallschnitt. 1: „Tiefe: 135 cm“; 2: „Tiefe: 210 cm“ 


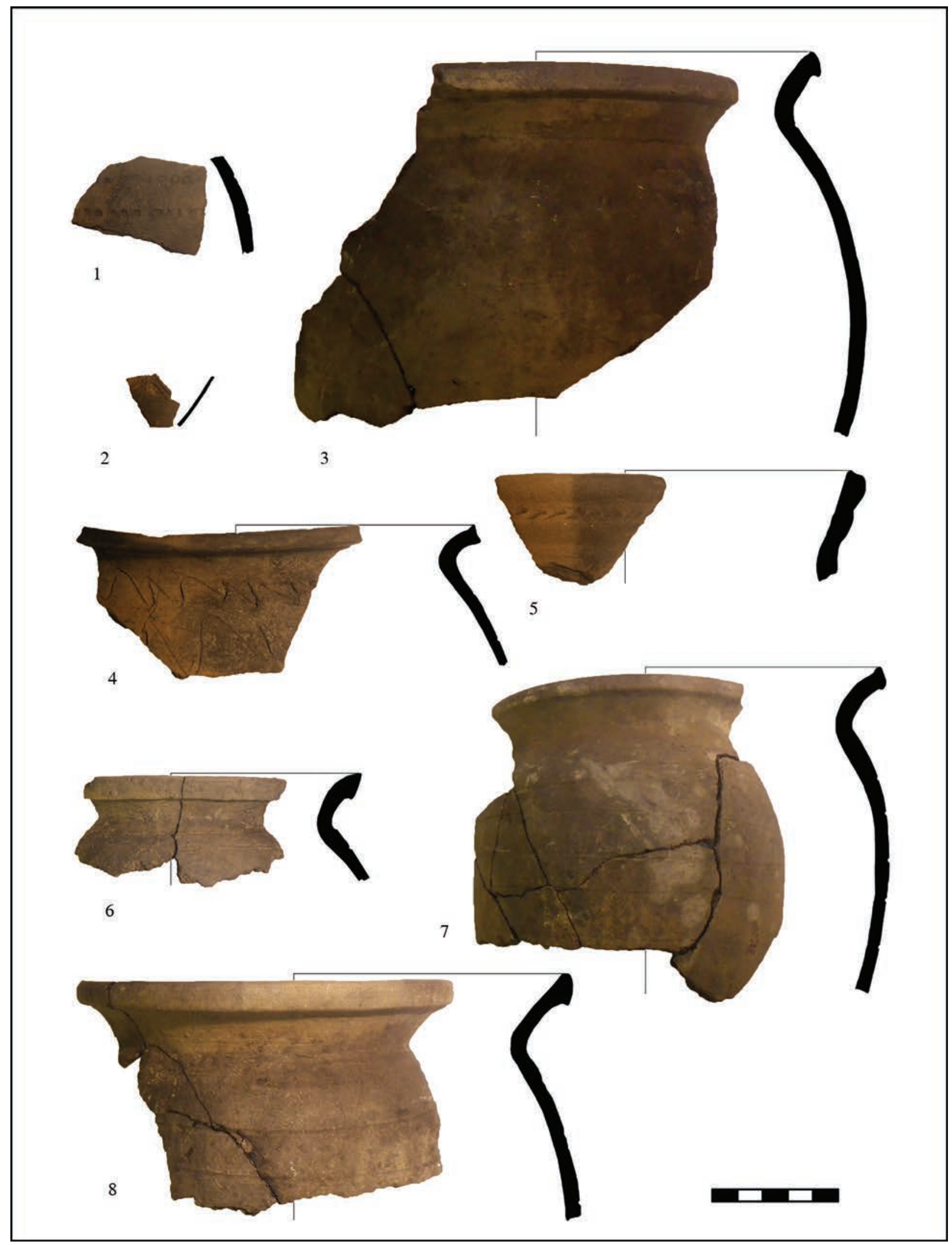

7. kép. Zalavár-Vársziget, kerámia az I. számú sáncátvágásból. 1-8: „Faltól keletre lévő dőlésből, M: 75-125cm” Abb. 7. Zalavár-Vársziget, Keramik aus dem I. Burgwallschnitt. 1-8: „Aus der Neigung östlich vom Wall, Tiefe: 75-125 cm“ 

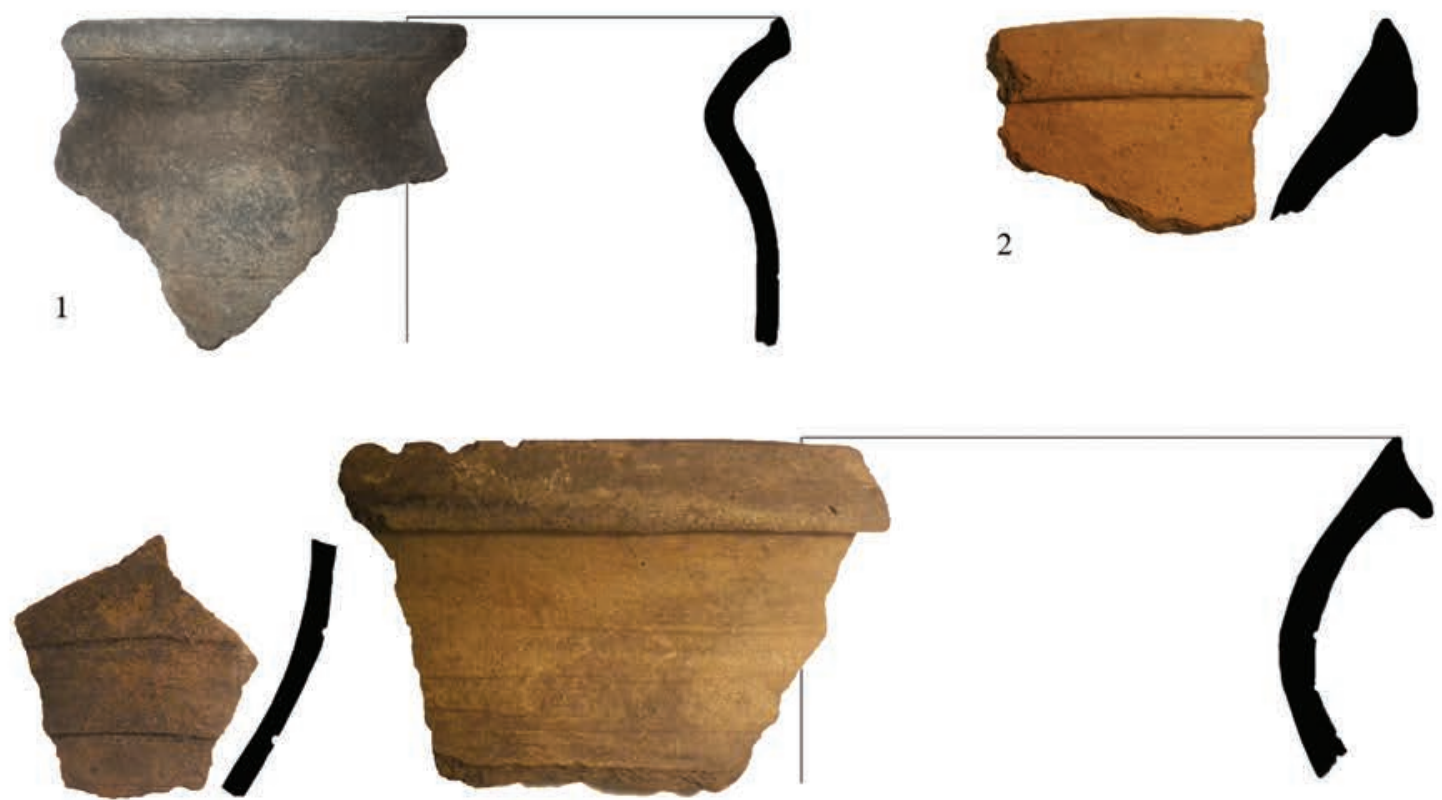

3

4

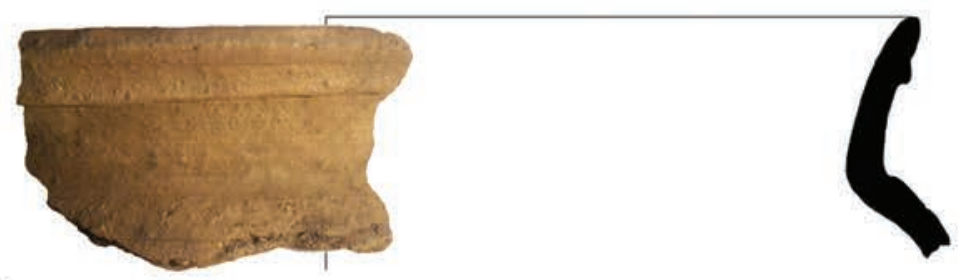

5
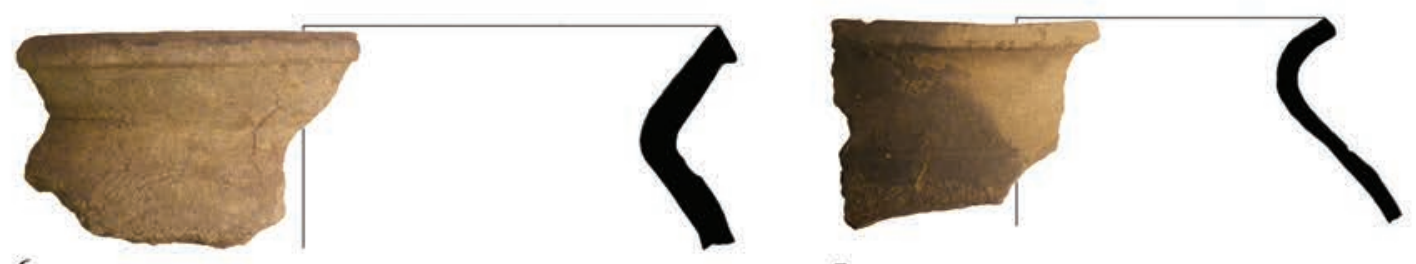

6

7

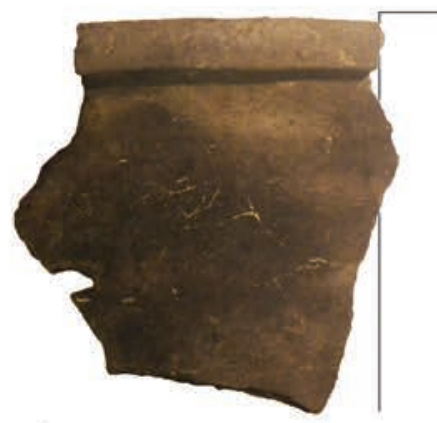

8

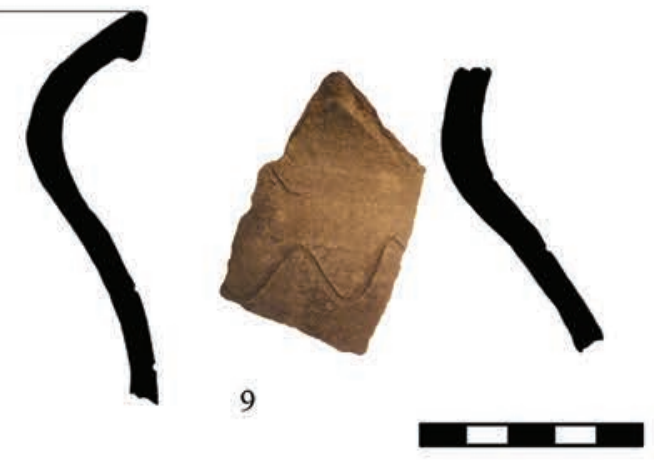

8. kép. Zalavár-Vársziget, kerámia az I. számú sáncátvágásból. 1-9: „Faltól keletre, M: 110-135cm” Abb. 8. Zalavár-Vársziget, Keramik aus dem I. Burgwallschnitt. 1-9: „Östlich vom Wall, Tiefe: 110-135 cm“ 


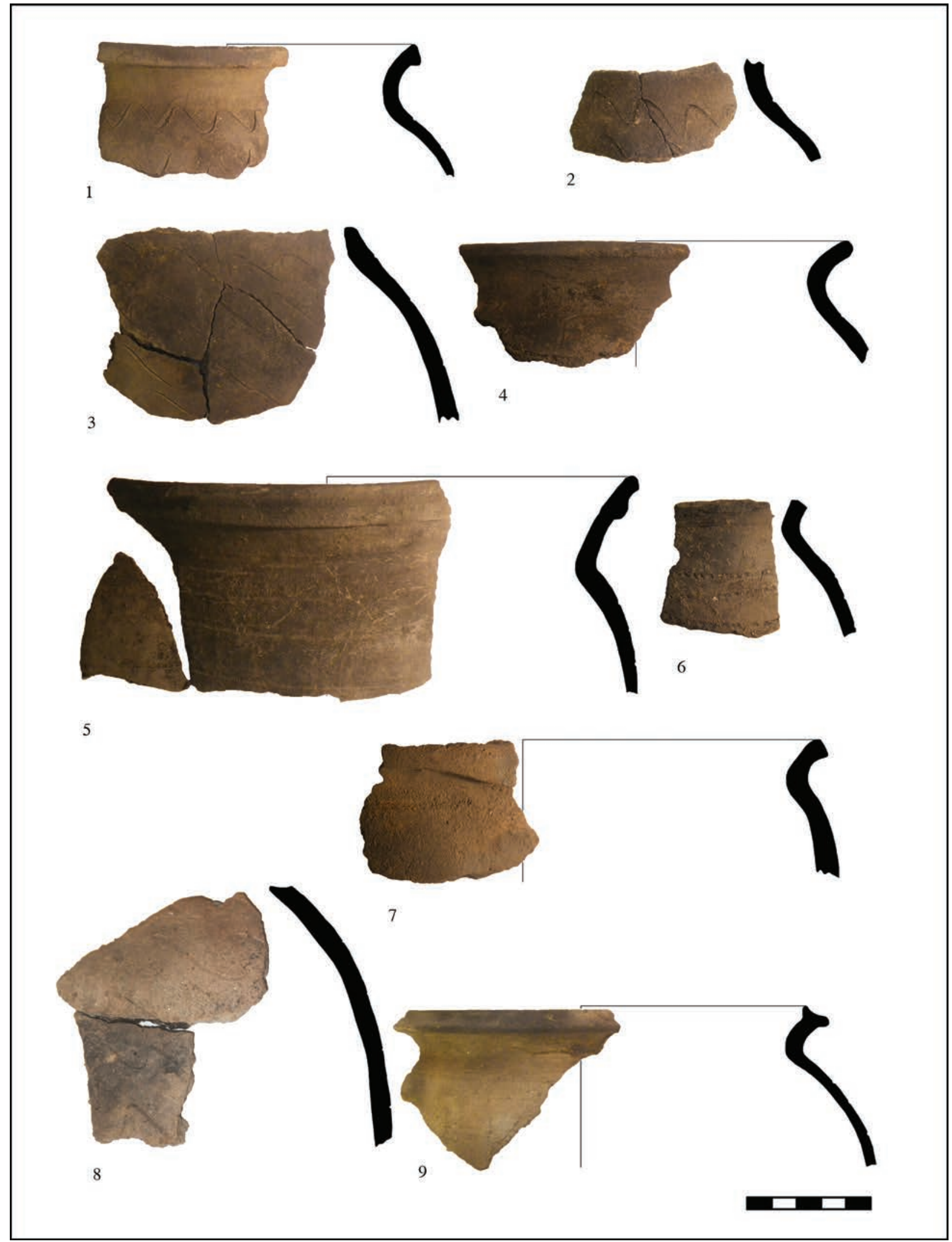

9. kép. Zalavár-Vársziget, kerámia az I. számú sáncátvágásból. 1-9: „Faltól keletre, M: 135-180cm” Abb. 9. Zalavár-Vársziget, Keramik aus dem I. Burgwallschnitt. 1-9: „Östlich vom Wall, Tiefe: 135-180 cm“ 


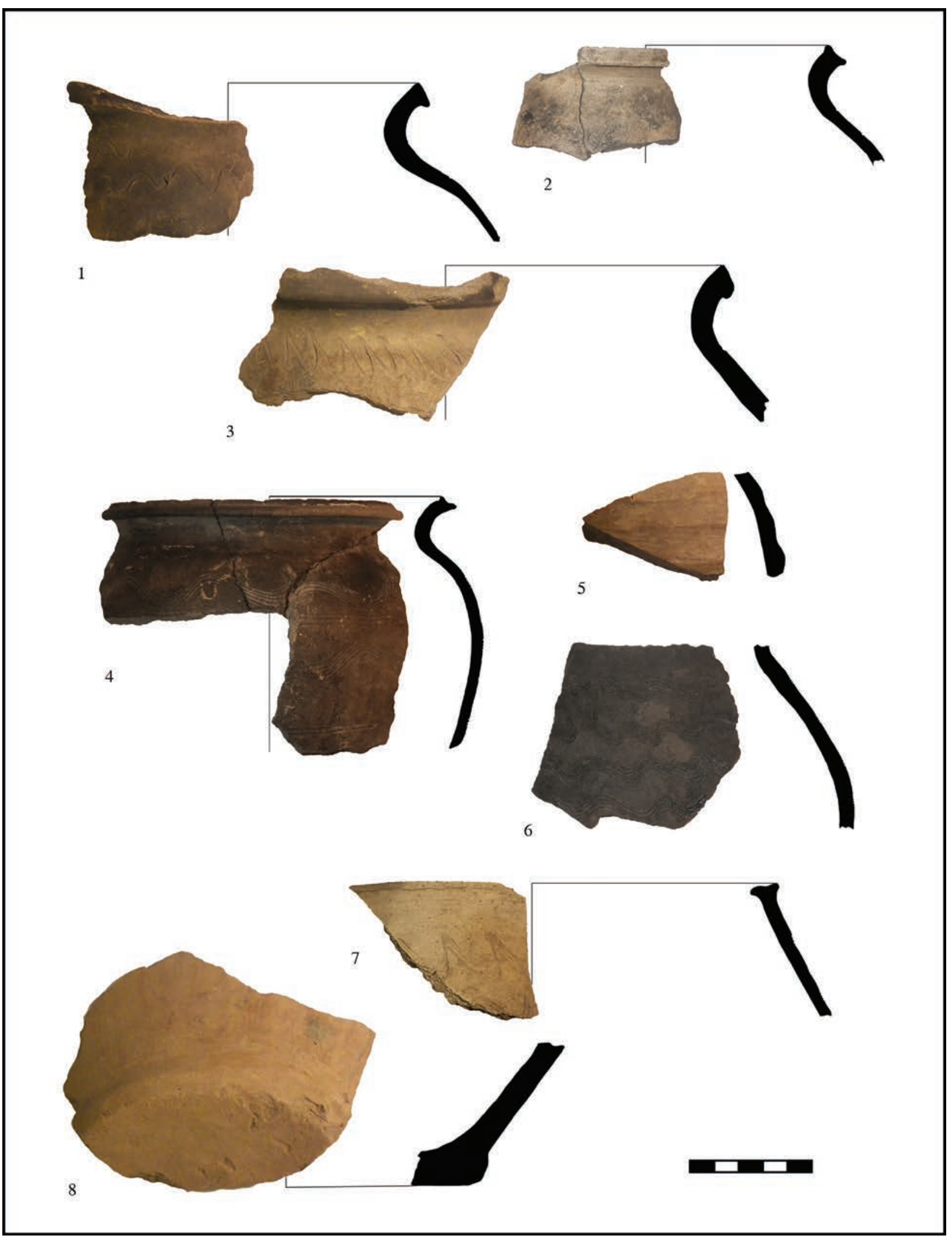


10. kép. Zalavár-Vársziget, kerámia az I. számú sáncátvágásból. 1: „Falmetszettől K-re”; 2: „Fal alatt és attól Ny-ra, M: 90 cm”; 3: „Fal déli végénél, a metszetben mutatkozó kő alatt, M: $25 \mathrm{~cm}$; $4:$ „Cölöplyukas faltól K-re, cölöptetők alatt $-15 \mathrm{~cm}$; 5: „Falmetszet DNy-i sarkától D-re (helyesen K-re), cölöplyukas fal oldala, M: cölöptetőktól 30 cm”; 6, 8: „Cölöplyukas fal tetejétől, M: 42-55 cm”; 7: „Metszet É-i kőfala (helyesen valószínúleg K-i; a többi égtáj ennek megfelelóen) D-i végétől DNy-ra a fal mellett, a felső szint alatt"

Abb. 10. Zalavár-Vársziget, Keramik aus dem I. Burgwallschnitt. 1: „Östlich vom Wallschnitt”; 2: „Unter dem Wall und westlich davon, Tiefe: $90 \mathrm{~cm}$ “; 3: „Am südlichen Ende des Walles, unter dem im Schnitt liegenden Stein, Tiefe: $25 \mathrm{~cm}$; 4 : „Östlich von der Pfostenmauer (d. i. die árpádenzeitliche innere Burg), Tiefe vom oberen Pfostenende $15 \mathrm{~cm}$; 5 : „Südlich (eigentlich östlich) von der südwestlichen Ecke des Wallschnittes, die Seite der Pfostenmauer, Tiefe vom oberen Pfostenende $30 \mathrm{~cm}$; 6, 8: „Vom oberen Ende der Pfostenmauer, Tiefe: $42-55 \mathrm{~cm}$; 7 : „Südwestlich vom südlichen Ende der nördlichen Steinmauer im Burgwallschnitt (eigentlich wahrscheinlich östliche Steinmauer, d. i. die äußere Burg; die weiteren Himmelsrichtungen dem entsprechend), neben dem Wall, unter der oberen Schicht"

kerámiakészítés hagyományának változásában sikerült megfigyelni néhány tendenciát. ${ }^{68}$

A biztosan az 1950-es évek sáncátvágásaihoz köthető leletanyag a Magyar Nemzeti Múzeum gyújteményében összesen 361 tételt számlál. A következetlen névhasználat, az árok, átvágás, metszet, külső várfal megjelölések szinonimaként való szerepeltetése miatt további 57 edényt vagy edénytöredéket csak kérdőjelesen lehet valamelyik átvágáshoz (I-IV.) kapcsolni. Az átvágásokból előkerült leletanyag eloszlása nem egyenletes. A sáncból származó, összesen 418 db kerámia közül $237 \mathrm{db}$, vagyis az összesnek több mint a fele (56\%) egyetlen átvágás, az I. számú leletanyagát reprezentálja.

$\mathrm{Az}$ I. sáncátvágás a Vársziget leghosszabb ideig lakott területén húzódik (lásd 1. kép). Vastag feltöltési rétegek fedik, így a teljes metszetsor a sánc alapozási rétegéig, illetve a feltárás határáig eléri a 3 métert. A rekonstruált metszetrajzon a fa-föld szerkezet feletti szakaszon 1-1,3 méter közötti vastagságot mutatnak a kevert homokos, homokköves és téglaomladékos rétegek, amelyek a sáncon kívül meredeken lejtenek, így itt ugyanezek a rétegek 2-2,5 méteres mélységig nyúlhatnak. A begyújtött kerámia nagy része innen, az egykori falon kívüli szakasz kevert omladékából származik. Ezek a felső, kevert rétegek középkori és Árpád-kori kerámiát tartalmaztak; köztük került elő (-135 cm mélységből) az egyetlen, majdnem ép cserépbogrács (6. kép). A „faltól K-re eső dőlésből", 75-180 cm közötti mélységből kerültek elő a 7-9. képeken bemutatott leletek is, amelyek döntően Árpád-kori csigavonalas, egyszerú hullámvonalas és fogaskerékdíszes fazéktöredékek. Helyenként azonban már itt is feltúnnek az inkább a 9-10. századra jellemző jegyek, mint a hullámvonalköteg vagy a ferdén

68 A sáncátvágás leletanyagának feldolgozását, a sánc rétegeihez való kötését és a kerámia változásának tendenciáit kíséreltem meg felvázolni: GERGELY s. a. levágott peremkiképzés szögben törő nyakkialakítással (pl. 7. kép 2, 6; 8. kép 1, 6). A következő, többé-kevésbé beazonosítható hely és/vagy réteg, ahonnan leletanyagot gyújtöttek, a "fal” kőomladéka alatti és az ún. "cölöplyukas fal” (vagyis az Árpád-kori monostor körítőfala) alatti szürke agyagréteg a kutatóárok nyugati végében. ${ }^{69} \mathrm{Az}$ erődítés falának kövei közül és alól származó leletanyag döntően 9. századi volt, míg a kutatóárok nyugati szakaszán, a monostor körítőfala alatti szürke agyagos rétegból és a sánc cölöpeinek jelentkezési szintjéből kizárólag 9. századi kerámia származott (10-11. kép). Ezt a leletanyagot már egyértelmúen a hullámvonal- és vízszintes egyenes vonalköteg-díszítés jellemzi. Napvilágot látott közöttük az igen jó minőségú, asztali díszedényként szolgáló polírozott sárga kerámia több darabja is (10. kép 5, 8; 11. kép 1, 6-9). Ennek az edénytípusnak a nagyarányú jelenléte a sáncátvágásban és a környezố szelvényekben a korabeli udvarház közelségét jelzi.

A sziget keleti földnyelvének déli peremén lévő II. sáncátvágásból jóval kevesebb, összesen 34 leltári tételt számláló kerámiaanyag került a múzeumba. Ezek közül nyolc darabnál merült fel az Árpád-kori keltezés, amelyek egyrészt az átvágáshoz csak bizonytalanul köthető ún. „II. árok"-ból, másrészt annak is a felső 40-50 centiméteréból származnak. A felső, köves és omladékos rétegek vegyesen tartalmaztak 9. századi és Árpád-kori kerámiát, míg a sánc eredeti rétegeiben, a cölöpsorok kiindulási szintjén, kb. 1 méter mélységben kizárólag kavicsos és meszes soványítású, jellegzetes 9. századi cserepek voltak. Ilyenek a 12. képen bemutatott, 70-100 cm mélységből, a fal kövei közötti rétegből, illetve a faföld sánc kötött feltöltési rétegéből származó darabok: a durva felületư, nagy szemcseméretú,

69 A leletek begyújtési helyének visszaazonosítását nehezíti, hogy a helymegjelölést a pontosság jegyében túlbonyolították, viszont az égtájak meghatározása néhány visszaellenórizhető ponton biztosan téves. 


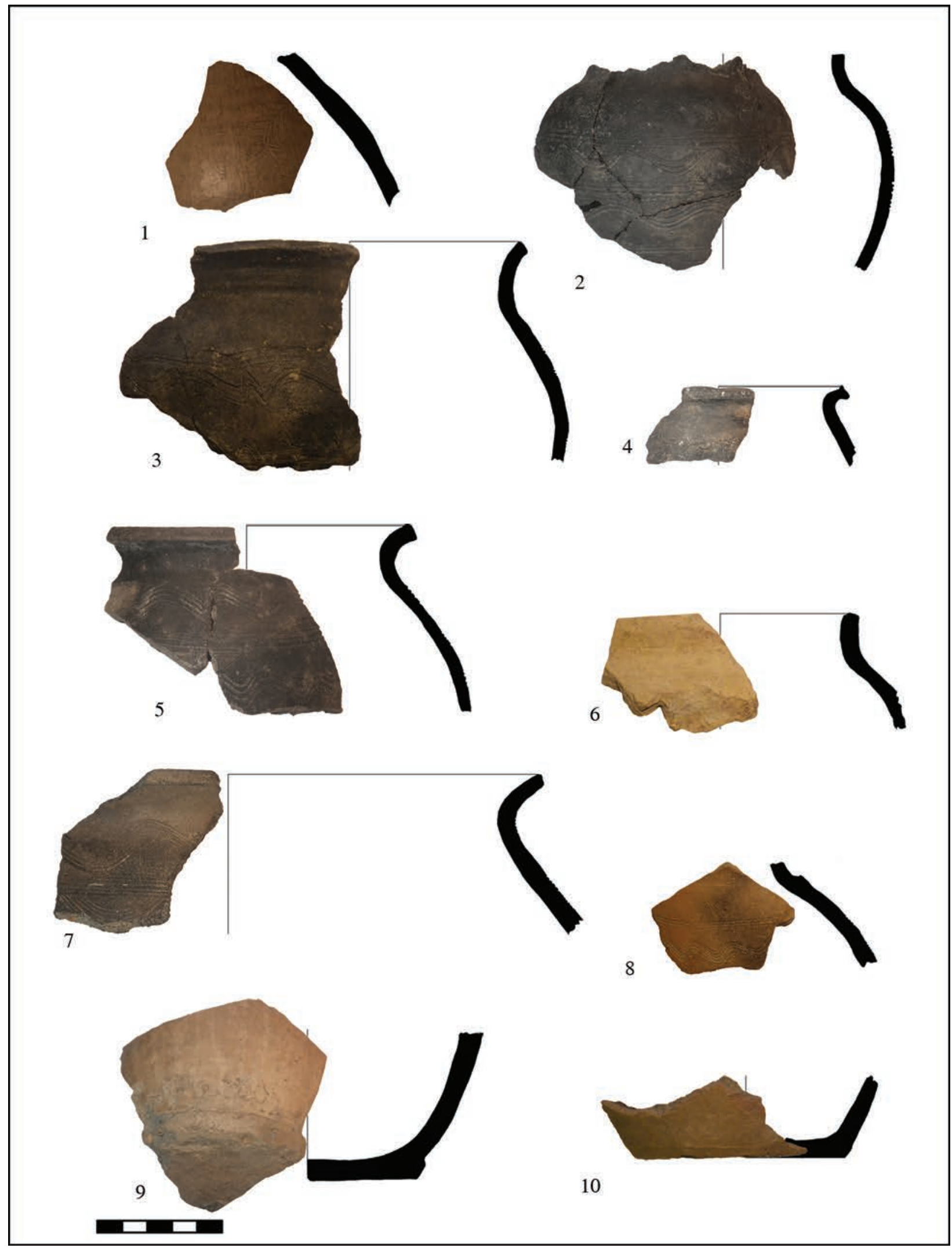

11. kép. Zalavár-Vársziget, kerámia az I. számú sáncátvágásból, a sánc cölöpeinek rétegéből. 1, 3, 5-8, 10: „DNy-i saroktól D-re (helyesen K-re) 260, illetve 420-560 cm-re, a cölöpök jelentkezési szintjétől -36-45 cm mélységben”; 2, 4, 9: „Cölöplyukas faltól K-re, cölöptetők alatt -15 cm"

Abb. 11. Zalavár-Vársziget, Keramik aus der Schicht der Pfosten, in der Schanze im I. Burgwallschnitt. 1, 3, 5-8, 10: „Südlich (eigentlich wahrscheinlich östlich) von der südwestlichen Ecke, Tiefe 260 bzw. 420-560 cm, unter dem Niveau der Erscheinung der Pfosten -36-45 cm“; 2, 4, 9: „Östlich von der Pfostenmauer, unter dem oberen Pfostenende -15 cm“ 


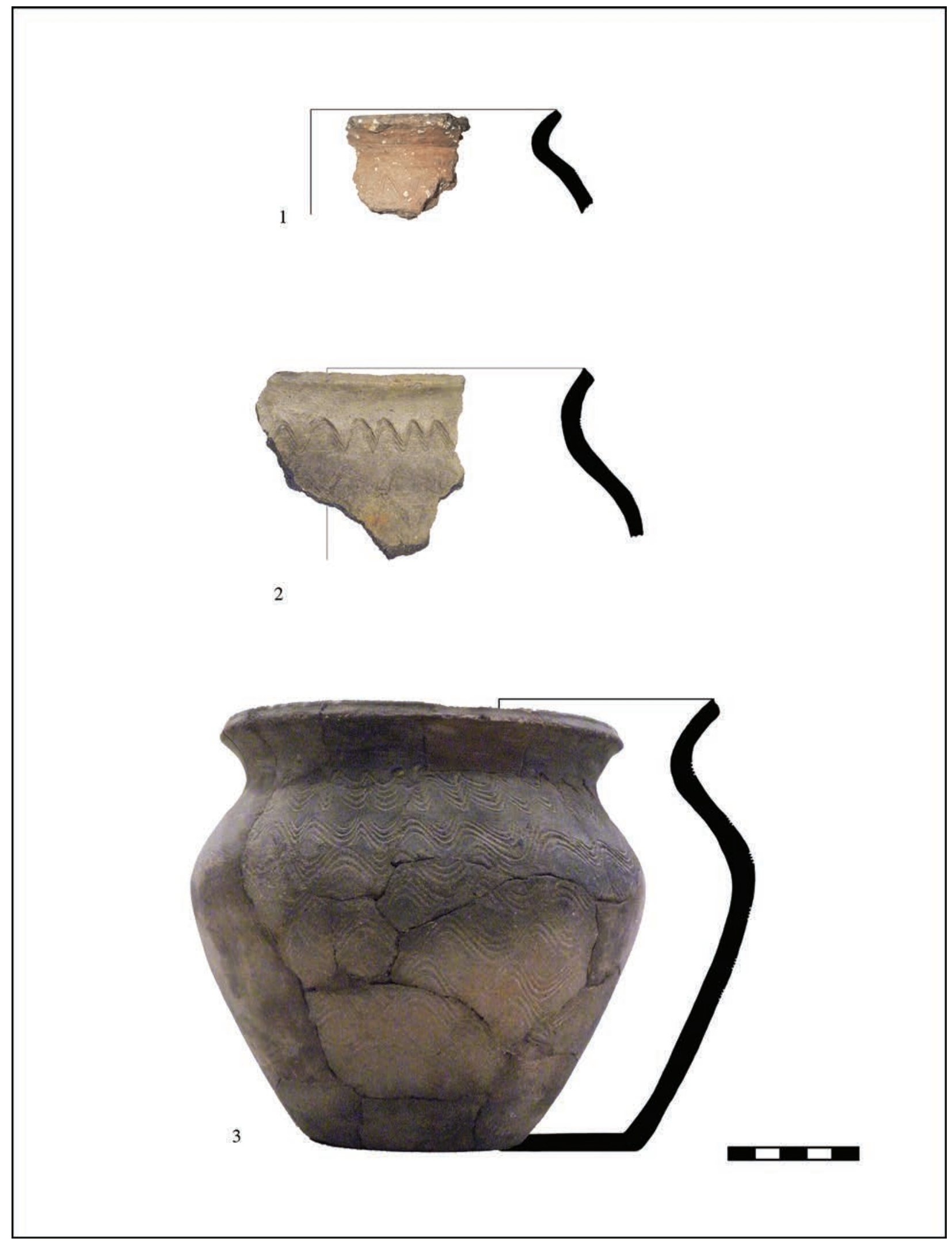

12. kép. Zalavár-Vársziget, kerámia a II. számú sáncátvágásból. 1: „Fal mellett, M: 70 cm”; 2: „II. árok, M: 100 cm”; 3: „II. árok, gerendák szintjében és alatta"

Abb. 12. Zalavár-Vársziget, Keramik aus dem II. Burgwallschnitt. 1: „Neben dem Wall, Tiefe: 70 cm“; 2: „II. Graben, Tiefe: 100 cm“; 3: „II. Graben, im Niveau der Balken und unter ihnen“ 
tört meszet tartalmazó (12. kép 1), valamint az apró kavicsos soványítású, hullámvonalkötegdíszítésú (12. kép 2) peremtöredékek és a kvarchomokos, széles szájú, erős vállú, az alja felé szúkülő, bikónikus formájú, az edénytest háromnegyedén sûrű hullámvonalkötegekkel borított felületú edény (12. kép 3).

A III. átvágásban - korabeli elnevezése szerint "erdei metszetben" -, a sziget északnyugati csücskében 83 darab/tétel kerámia került elő. Közülük tizenegynél szerepel megjegyzésként, hogy az Árpád-korra keltezhető. Ezek döntően a kutatóárok keleti, azaz a sziget belseje felé eső szakaszában, átlagosan 60-90cm közötti mélységben vagy a fal köveinek omladékában láttak napvilágot. A törmelékes, omladékos réteg alatt, a sánc égett és döngölt agyagos rétegeiben már 30-65 cm mélységben többnyire 9. századi kerámiát tártak fel, az alatta húzódó, szürke agyagos és mocsári földben (-140 cm-ig), a fal kövei között, a gerendakonstrukció és a temetkezések szintjében pedig kizárólag jó minőségú 9. századi kerámiát. Ezek között eredetileg meszet tartalmazó, lyukacsos felületúre kiégett, egyenes és hullámvonalkötegekkel díszített (13. kép 1, 7), valamint kavicsos soványítású, sprőd felületú edénytöredékek (13. kép 8) fordultak elő. Nem csak a kutatóárok anyagában, de általánosságban is a legnagyobb arányban fordulnak elő a kvarchomokos, homokos adalékanyagú edények, köztük egészen jó minőségú, csillámos és finom anyagú, kenődő tapintású darabok (13. kép 3, 5). A polírozott felületú díszkerámia jelenlétét négy töredék jelzi (13. kép 9). Az eddig bemutatott kerámia - a néhány polírozott palackhoz vagy más funkciójú díszedényhez köthető darabok kivételével - mind fazékhoz tartozik. A fazekak az eddig vizsgált leletegyüttesek elemzése alapján az egykori edénykészlet 85-95\%-át teszik ki. Ritkaságnak számít a minőségileg a házi kerámia csoportjába sorolható, funkcionálisan azonban külön kategóriát alkotó tálak csoportja. Az átvágásban előkerült darab (13. kép 6) az egyenes oldalú, erősen összeszúkülő aljú (fordított csonka kúp alakú) mély tálak típusába sorolható.

A IV., a Vársziget déli nyúlványát É-D-i irányban átvágó kutatóárok 65 tételt számláló kerámiaanyagot hozott felszínre. Az I. átvágáshoz hasonlóan vastag feltöltési rétegeket mutatott, helyenként elérte a 3 métert. A kutatóárok északi, vagyis erődítésen belüli végéből, a föld-fa konstrukció tövében észlelt árok leletanyagából és a kőomladékból származott a 8 db biztosan Árpádkoriként meghatározható darab. (Idesorolható a 14. kép 1. kerámiája is.) Az erődítéshez tartozó rétegek (homokos és iszapos rétegek, valamint a sánc alapozási szintje 120-165cm mélységben) 9-10. (?) századi kerámiát tartalmaztak. A leletek zömét 9. századi standardizálódott minőségú, kvarchomokos soványítású, vegyes égetésú, hullámvonalköteggel és egyenes vonalköteggel díszített fazéktöredékek tették ki (14. kép 4-5), de előkerült egy lapos sütőtál töredéke is (14. kép 3). Ritkaságnak számít az edénytest közepén, a has vonala alatt ferdén behúzott egyenes vonalköteg dísz (14. kép 6). A kövecsesi sírba tett és egyes, települési objektumból származó edényekkel ${ }^{70}$ való rokonsága miatt valószínúsíthetően már a Karoling-virágkort követő időszak edénymúvességének emléke lehet az a gömbös testú, zömök edény, amelyet a hasán három sorban mélyen bekarcolt, szabályos hullámvonalakkal (vagy öszszetorlódott mintájú hullámvonalkötegekkel) díszítettek (14. kép 2).

A sánc feltöltésének leletanyagát abszolút korhatározóként nem, csupán post quem értelmezéssel vehetjük számításba. A sáncátvágásokból előkerült leletek földbe kerülése nyilvánvalóan a sánc megépítésével, illetve feltöltésével van öszszefüggésben. Rétegei közé a környező korábbi és korabeli települési horizont szemete került be. A sánchoz tartozó eredeti, bolygatatlan rétegek - a szárazon rakott falmaradványok, a gerendaszerkezetek, illetve a cölöprendszer - leletanyaga kizárólag 9. századi anyagot tartalmazott. Árpádkori kerámia csupán az erősen köves, felsőbb omladékrétegekben fordult elö, ezért a 9. század végénél későbbi keltezés nem lehet indokolt.

\section{Párhuzamok és keltezés}

A sánc pontos méretének, talpszélességének meghatározása a hiányos és bizonytalan megfigyelések miatt problematikus. Teljes szélessége a cölöpökkel és a kőfallal 5 és 10 méter közé tehető. A bizonytalanságot a korábbiakban taglalt tényezők okozzák. Mérete, szerkezete és jellege - a kővel való köpenyezés, a valódi kazetták hiánya, a bázist jelentő alsó rost-/rácsszerkezettel/gerendázattal stabilizált, kettős vagy többszörös cölöpsor közé döngölt föld - idegen korai Árpádkori váraink között. ${ }^{71}$ A Mordovin Maxim által világosan elkülönített, az ország két távoli régiójára jellemző ispáni várak típusaival nem rokonítható. ${ }^{72}$ Északnyugat-Magyarország és Erdély

70 Cs. Sós 1984, T. II.3, 5; LI.2, 5; LIV.3.

71 Összefoglalóan: MoRDOVIN 2010; BóNA 1998. Az ispáni várakról többek között: BuZÁs 2006; WOLF 2001. A korai magyar sáncvárak kérdéséről: NovÁKI-SÁNDORFI 1981; NoVÁKI 1964 stb.

72 Mordovin 2010, 118, 124. 
területére többnyire a kazettás szerkezetú várak jellemzőek, amelyekben a kőfallal való köpenyezés általában a várak későbbi periódusában valósult meg, ${ }^{73}$ míg az északkeleti vidék sáncai egykomponensú, rácsos szerkezetet mutatnak. ${ }^{74}$

A zalavári sánc szerkezetét több szerkezeti elem együttes jelenléte jellemzi, ami alapján Mordovin Maxim 3.b vagy 3.c - vagyis az úgynevezett többkomponensú erődítések rostos vagy rácsos belső vázú, külső kőfallal ellátott - típusába sorolható. ${ }^{75} \mathrm{~A}$ két típus közötti választás azért bizonytalan, mert míg a rácsszerkezet teljes felmenő belső vázat, önhordó szerkezetet feltételez, Zalaváron a gerendák mindenütt csak két rétegben feküdtek egymáson, felmenő rész nem volt. A rostos szerkezet sajátossága ugyanakkor, hogy csupán az alapozás stabilitását kívánja biztosítani, függőleges kiterjedése nincsen. Zalaváron azonban a gerendák, deszkák és karók egymásra merőleges elhelyezése szabályos rácsszerkezetet mutat.

Az erődítés egészét Zalaváron sem lehet egyetlen egységes sémába kényszeríteni: bizonyos szakaszokon hiányzik a cölöpsor, a rácsszerkezet nem követhető végig az erődítés teljes hosszán, máshol pedig a falmaradványok és az omladék mutatnak eltéró képet. Ebben Zalavár igazodik ahhoz az általános jelenséghez, hogy a kora középkori erődítések nem kizárólag egy szerkezeti megoldás szerint épültek. Már Nováki Gyula felhívta erre a figyelmet, ${ }^{76}$ legutóbb pedig Feld István Borsod vára kapcsán vetette fel a különböző szerkezeti elemek egyidejúségének lehetőségét. Véleménye szerint egyszerú építéstechnikai okokból alkalmazták egy időben a belső faváz két alapváltozatát, azaz az ún. rácsos, illetve a kazettás, kamrás vagy rekeszes szerkezetet. ${ }^{77}$ Pozsony esetében is csak egy-egy rövid szakaszon figyelhető meg a rácsos gerendázat, máshol pedig kazettás szerkezetet dokumentáltak. ${ }^{78}$

A zalavári példából kiindulva egészen egyszerú okok is eredményezhetik a szerkezeti eltérése-

73 Egyes északnyugat-magyarországi sáncokra vonatkozóan példaként: GÖMÖRI 2002; TOMKA 1986; TOMKA 2006. A 10-14. századi erdélyi várépítészetről összefoglalóan: ȚIPLIC 2007.

74 Például: Mordovin 2013; NÉMETH 1973; NOVÁKI-SÁRKÖZYFeld 2007; Wolf 1996; Wolf 2001; Wolf 2008.

75 Mordovin Maxim széles körú gyújtése alapján az összetett szerkezetú, többkomponensú kőfalas sáncok elterjedése kifejezetten Csehországra jellemző. Megjelenésük a 9. századtól adatolható. A 3.b rostos szerkezetet elsósorban a cseh váraknál alkalmazzák, míg a 3.a rácsos szerkezetú megoldás inkább a lengyel és északnémet területek erődítéseit jellemzi; vö. Mordovin 2010, 120.

76 NOVÁKI-SÁNDORFI 1981, 137.

77 FELD 2010, 497.

78 ŠTEFANOVIČOVÁ 1998. ket. Legkézenfekvőbb az eltérő ásatási módszerekben keresni az indokot: az utóbbi évtizedek részben hitelesító ásatási tapasztalatai alapján felvethető, hogy egyes jelenségeket a feltárás során nem figyeltek meg. Az építés idején a szükségszerúség és az anyagtakarékosság is logikus szempont lehetett, elképzelhető, hogy eredetileg is csak bizonyos szakaszokat láttak el rácsszerkezettel. A kisebb-nagyobb különbségeket az eltéró munkamódszer vagy az utólagos javítások, pótlások során alkalmazott eltéró szerkezeti megoldások is eredményezhették. Procházka véleménye szerint a fakonstrukciós erődítések legfeljebb ötven évig élhettek, ezért szükséges volt folyamatos karbantartásuk és megújításuk. ${ }^{79}$ Ezek a tényezók akár együttesen, akár külön-külön is okozhatták a szerkezeti anomáliákat Zalaváron.

A Cs. Sós Ágnes által rekonstruált zalavári 9. századi, egyszerú paliszád párhuzamai széles körben fellelhetők. Ezek azonban általában egyegy nagyobb településen belül térelválasztó, határoló kerítésként fordulnak elő, udvarházak erődítéseként, vagy - ritkán - a központok korai kerítéseként/védelméül (?) szolgáltak. Jól ismertek az udvarházat körító paliszádok többek között Břeclav-Pohanskóról, ${ }^{80}$ Gars-Thunauból ${ }^{81}$ vagy akár a szomszédos Zalaszabar-Borjúállásszigetről. ${ }^{82}$ A Mikulčice VI. számú temploma körüli temetőt paliszádra utaló árok határolta. ${ }^{83}$ Staré Město településkomplexumának központi szigetét, a Szent György-sziget déli, elővári részét a feltárt paliszádnyomok alapján a korábbi kutatás feltételezése szerint erődítés vette körbe. Újabban a 8. századra utaló dendrokronológiai adatok ismeretében és egyes hitelesító ásatások eredményei révén kétség merült fel az erődítés funkciót illetôen. Inkább a korai település mocsár elleni vagy átkeléshez kapcsolódó védmúveként, de leginkább bizonytalan rendeltetésú jelenségként értékelik. ${ }^{84}$

A nagyméretú, korábban Árpád-koriként meghatározott zalavári sánc legjobb analógiái a morva központokból állnak rendelkezésre: Staré Město egyes 9 . századi külső védmúvei a zalavárihoz hasonló szerkezetet mutatnak. A Salaška patak menti Rybníky vizenyős mező összetett erődítésszakasza öt sorban elhelyezett, részben fonott cölöpszerkezetú, amelyet keresztirányú gerendákkal merevítettek, így talpszélessége el-

\footnotetext{
79 ProcházKa 1998, 363-370; MÜLler 1994, 95.

80 DOSTÁl 1975.

81 Szameit 1998, 75-76; Herold 2008, 288-290; Herold 2011, 521-524, Abb. 4-7.

82 MÜLLER 1994.

83 Hladík-MaZuch-PolÁČEK 2008, 201, Abb. 13.

84 GALUŠKA 2008.
} 


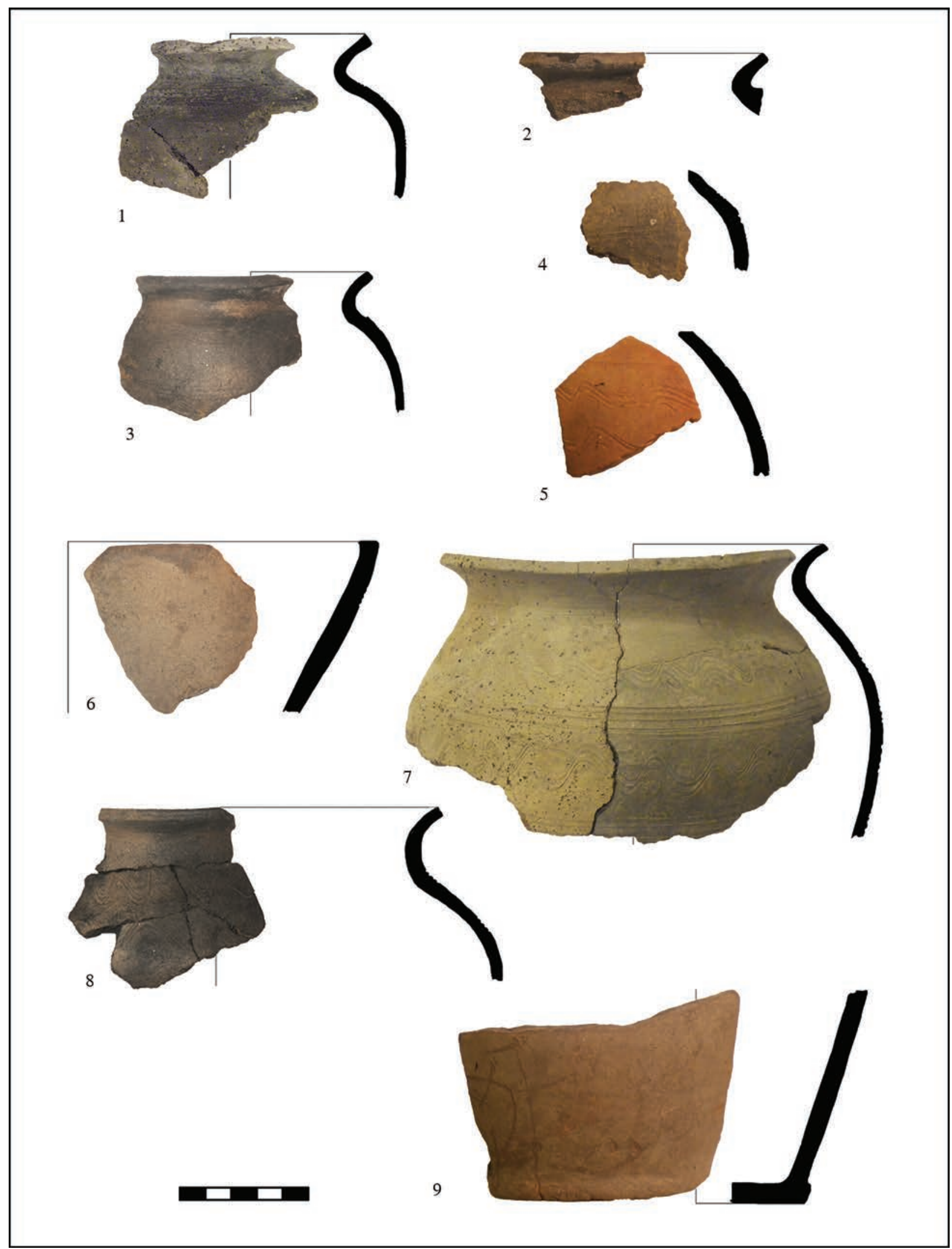

13. kép. Zalavár-Vársziget, kerámia a III. számú sáncátvágásból. 1: „III. árok K-i meghosszabbítása, 4. réteg, M: 60-90cm”; 2, 6: „10. szelvény (valószínúsíthetóen a 10 méteres szakaszpont környéke), M: 140 cm”; 3, 9: „Fal kövei között, M: 70 cm”; 4, 7: „Falon belül, M: 60-80 cm”; 5: „Vörös föld”; 8: „Az árok Ny-i felében”

Abb. 13. Zalavár-Vársziget, Keramik aus dem III. Burgwallschnitt. 1: „Verlängerung des Grabens III. nach Osten, 4. Schicht, Tiefe: 60-90 cm“; 2, 6: 10. Abschnitt (wahrscheinlich beim Streckenpunkt $10 \mathrm{~m}$ ), Tiefe: $140 \mathrm{~cm}$; 3, 9: "Zwischen den Steinen des Walles, Tiefe: 70 cm“; 4, 7: „Innerhalb des Walles, Tiefe: 60-80 cm“; 5: „Rote Erde“; 8: „In dem westlichen Teil des Grabens" 


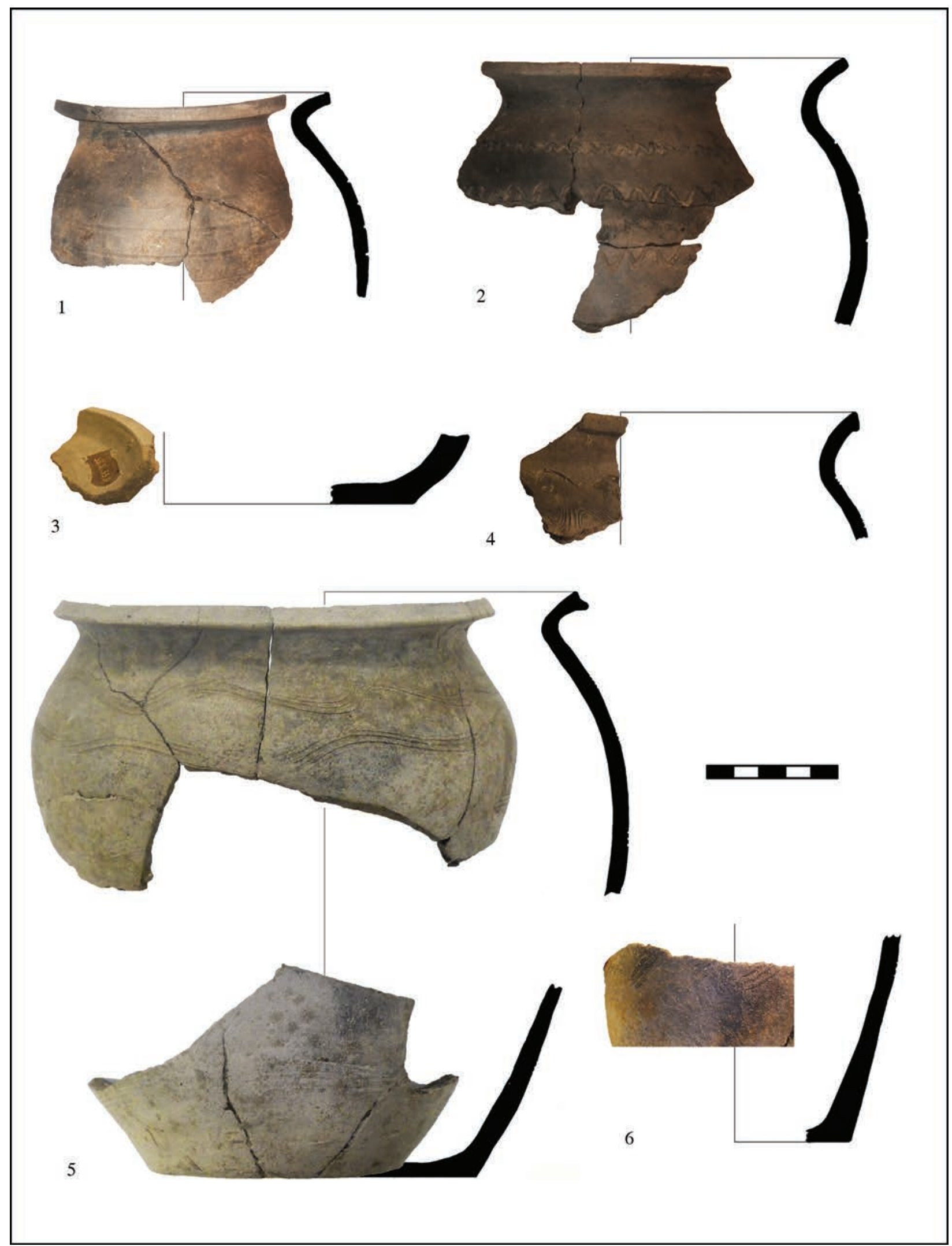

14. kép. Zalavár-Vársziget, kerámia a IV. számú sáncátvágásból. 1: „Árok Ny-i végéből”; 2-4: „M: 120-145cm”; 5: „M: 160-165 cm, É-i végétől K-Ny-i irányba húzódó árokból”; 6: „Falmetszet D-i fele, homokos rétegbe rakott kövek között, M: 85-120 és $145-165 \mathrm{~cm}^{\prime \prime}$

Abb. 14. Zalavár-Vársziget, Keramik aus dem IV. Burgwallschnitt. 1: „Aus dem westlichen Ende des Grabens“; 2-4: „Tiefe: 120-145 cm“; 5: "Aus dem Ost-West orientierten Graben am nördlichen Ende des Burgwallschnittes, Tiefe: 160-165 cm"; 6: „Südliche Hälfte des Burgwallschnittes, zwischen in die Sandschicht gesetzten Steinen, Tiefe: 85-120 und 145-165 cm“ 
érte a hat métert. ${ }^{85}$ Jobb analógiaként kínálkozik a településagglomeráció rybárnybeli erődítése. Itt ugyanis a hármas cölöpsorra épülő, keresztgerendákkal stabilizált sánc előtt már a szárazon rakott köpenyfalazat is megjelenik, amellyel együtt a sánc teljes szélessége 8 méter körül lehetett. ${ }^{86}$ Ezt a várfalépítési technikát Procházka a 9. századi morva erődített településekre általánosan jellemzőnek tartja. ${ }^{87}$

Rekonstrukció nélkül, de alap- és metszetrajzokkal publikálták és értékelték újra legutóbb Mikulčice hosszú szakaszokon feltárt külső erődítéseit a kapukkal és a szigetek közötti hídszerkezetekkel, amelyek szerkezete és jellege nagyon hasonlít a Zalaváron találtakéhoz. ${ }^{88} \mathrm{~A}$ nagy felületú kutatásoknak köszönhetően ugyanazokat a jellegzetességeket figyelték meg, amelyeket Zalavár-Vársziget északi szélén is tapasztalhatunk (lásd 3. kép). Az egykori erődítés kőfala nem eredeti helyzetében, hanem szabálytalan körvonalú omladék formájában jelentkezett, döntően az erődítés külső, kisebb mértékben a belső oldalán. Utóbbi oldalon a falat kíséró cölöpsort (cölöpsorokat) és többé-kevésbé szabályos kazettaszerkezetbe rendezett alsó gerendamaradványokat is eredeti helyzetükben dokumentálták, ahol a részben megégett, döngölt agyagrétegeket is megfigyelték. ${ }^{89} \mathrm{~A}$ fal külső oldalát feltehetően hasonló indokkal és a fal csúszását megakadályozandó, illetve a mocsár vagy folyó elleni védekezésül kisebb karókból álló sövényfonattal(?) és lefektetett deszkákkal óvták..$^{90}$

Břeclav-Pohansko újonnan megásott erődítése a legjobb párhuzamként említhetó. Metszetrajzai és leírása nagyon emlékeztetnek Zalavár erődítésére. A kívülről kővel köpenyezett, két cölöpsor/ paliszád közé döngölt (?) földből álló erődítmény alján, alapozási szintjében lefektetett tölgygerendákat találtak, amelyek a konstrukció rögzítését szolgálták ${ }^{91} \mathrm{Az}$ átvágásról készített metszetrajz is erősen emlékeztet a zalavári III. sáncátvágás Méri-féle rajzához. ${ }^{92} \mathrm{Az}$ ábra szerint a sánc szélessége - csak a belső magot és a kőfalat számítva - 6 méter körülire tehetó. Külső és belső szélei, a szerkezethez tartozó egyéb elemek, támasztókarók és külső paliszád azonban tovább növelik szélességét. Ezek az adatok teljesen megegyeznek a zalavárival. Az átvágás során a sánc alapo-

85 GALUŠKA 1998, 345, Abb. 2.B.

86 GALUŠKA 1998, 345-346, Abb. 3.B; Schicksalsjahr 2007, Abb. 8.5.17.

87 PROCHÁZKA 1998, 363-370.

88 HLADÍK 2012

89 HLADíK 2012, Obr. 8-17.

90 HLADÍK 2012, 66.

91 DRESLER 2011, 63-65.

92 Dresler 2011, Abb. 4-5. zási szintje alatt a belső cölöpsor/paliszád árkát is megtalálták, és azt a nagyméretú, összetett szerkezetú, 881 után épült erődítés előzményeként értékelték. ${ }^{93}$ (Lásd Grynaeus András adatait a Függelékben.)

Nyitra, ${ }^{94}$ Pozsony, ${ }^{95}$ Pobedény ${ }^{96}$ erődítéseit azért nem lehet a legközelebbi analógiák között említeni, mert bár ezek is kővel köpenyezett, faföld szerkezetúek, de többnyire rácsos vagy kazettás belső szerkezetet hordoztak. Ugyanakkor a Nyitra és Pozsony között fekvő Majcichov 9. század végére keltezett eródítése és annak rekonstrukciója hasonlóságokat mutat a zalavári sánccal. ${ }^{97}$ Habár ezt is a kazettás szerkezetúek közé sorolták, a rekonstrukción nem jelennek meg a tényleges kazetták, összképe pedig hasonló benyomást kelt, mint amilyet Zalavár esetében feltételezhetünk. Ez rávilágít arra a tényre, hogy bár továbbra is a védmúvek szerkezeti elemeinek aprólékos, minden részletre kiterjedő vizsgálata jelenti a típusba sorolás, a csoportosítás alapját, a végeredmény, vagyis a megjelenés tekintetében az egymástól némileg eltérő konstrukciójú erődítések a valóságban nagyon hasonlíthattak egymásra.

Alsó-Ausztria területéről két kora középkori erődített magaslati települést lehet példaként felhozni: Gars-Thunau és Sand várát. Mindkét erődítésre a szárazon rakott köpenyfal jellemző. Míg Gars 9. században megépített sáncát kazettás szerkezettel látták el, ${ }^{98}$ Sand 926-930 között emelt vára a kőfal belső oldalán álló (a kazettákhoz igen hasonló) faépületekkel rendelkezett.99 Utóbbit összeköti a zalavári külső erődítéssel, hogy egy szakaszon itt is fatörzseket vagy bárdolt gerendákat helyeztek a földsánc alá, a cölöpök, cölöpsorok közé a sánc stabilitásának növelésére. ${ }^{100}$

A Karoling Birodalom központi területein sem lehet egységes Karoling-kori várépítészetről beszélni. ${ }^{101}$ A várak kialakítása a regionálisan eltéró fejlődési irányok, külső hatások, földrajzi és természeti környezeti tényezők következtében változó. A bajor és frank területek települései, Karoling központok, pfalzok eleinte, a települé-

\footnotetext{
93 DresLer 2011, 68, 75, Abb. 5. Lehetséges azonban, hogy itt is egyszerúen csak a sánc szilárdítását biztosító cölöpök mélyre ásott árkáról, a szerkezet stabilitását növelő megoldásról van szó.

94 BEDNÁR 1998

95 ŠTEFANOVIČOVÁ 1998

96 BiALEKOVÁ 1998.

97 Henning-RuttKay 2011, 265-266, Abb. 6.

98 SZAMEIT 1998, 74.

99 Felgenhauer-Schmidt 2002.

100 Felgenhauer-SCHMidt 2002, 385, 390, Abb. 3.

101 BRATHER 1998, 119.
} 
sek első fázisában nem voltak eródítve. ${ }^{102} \mathrm{Az}$ egész Európán végigsöprő várépítési hullám egyik kiváltó oka - a szociális, gazdasági és politikai fejlődés mellett ${ }^{103}$ - a magyar betörések sürúsödése lehetett. Ezt az időszakot az európai várépítészetben „magyar kori váraknak” is nevezik (ungarnzeitliche Befestigungen). ${ }^{104}$ A Rajnától keletre fekvő térségben már a 7. századtól kezdve álltak szárazon vagy habarccsal rakott kőfalú erődítések, illetve a római kori vagy Merowingkori előzményekkel rendelkező települések városfalait gyakran földdel feltöltött falakkal erősítették meg. Bajorországnak elsősorban az északi felében sokkal gyakoribbak a közép-európai példákhoz hasonló, fa-föld szerkezetú sánc elé felhúzott, szárazon rakott kőfalú erődítések. ${ }^{105}$ A Würzburg közelében fekvő Roßtal 6 méter szélesre tehető fa-föld sánca keresztgerendákkal merevített, keskeny, száraz kőpakolással ellátott. A sánc külső oldalát széles bermével, valamint árokkal szegélyezték, belső oldalán pedig földfelszíni épületek sorakoztak. ${ }^{106}$ Az Elba és az Odera folyók között, Mecklenburg-Vorpommern és Brandenburg területén, valamint a nyugati szlávok lakta teljes zónában is elsősorban a faföld szerkezetú, rácsos vagy kazettás szerkezetú erődítések jellemzőek, ${ }^{107}$ ahol a kő - a föld feltöltésében elszórva - többnyire csak a konstrukció súlyozására szolgált. Alsó-Szászország területén szintén alapvetően fa-föld szerkezetú ún. Ringwälle erődítések épültek a 9. századtól kezdve. ${ }^{108}$ Egyes változataikat azonban a ferde földfalakon és faszerkezeten kívül és belül kőköpenynyel látták el a stabilitás és a túztól való védelem érdekében. ${ }^{109}$

A régészetben az utóbbi idők legfontosabb eredményeit és változásait kétségkívül a természettudományos módszerek széles körú használata hozta meg. A kora középkori sáncok kutatásának előremozdításában a ${ }^{14} \mathrm{C}$ kormeghatározás és a dendrokronológia játszottak meghatározó szerepet. ${ }^{110}$ Joachim Henning és Matej Ruttkay együttmúködésének köszönhetően számos közép-európai sánc keltezését - és az új sáncátvágá-

\footnotetext{
102 ZоTZ 1993, 1995.

103 BRATHER 1998, 119

104 ETtel 2011, 459

105 ETTEL 2001, 202-207.

106 ETTEL 1998, 129-131; ETtel 2001.

107 Heussner-Westphal 1998. Példaként az egyes várakra: Berlin-Spandau: MÜLler-MÜlLER-MUČI 1983; StarigardOldenburg: MülleR-Wille 1991; Mecklenburg: DONAT 1984; Teterow: UnVERZAGT-SCHULDT 1963.

108 HeINE 1998.

109 AHRENS 1998.

110 HenNing 1998; Heussner-Westphal 1998; ITM 1999; StadLER et al. 2000; HENNING-RUTTKAY 2011.
}

sok révén akár szerkezeti leírását - kellett gyökeresen megváltoztatni. Az adatsorok alapján kirajzolódó tendencia szerint a morva erődítések jelentős része csak a 9. század legvégén, a 9-10. század fordulóján, 111 jól adatolt történeti események következményeként épült fel. Az eddig felsorakoztatott régészeti érvek és a velük egybevágó dendrokronológiai eredmények alapján ebbe a várépítési hullámba illeszkedik ZalavárVársziget korábban feltárt, most újraértékelt erődítése is.

\section{Összefoglalás}

Zalavár-Vársziget erődítési rendszerének kutatása során a sziget peremén két eltéró korú, közel párhuzamos erődítést tételeztek fel. Az elképzelés szerint a 9. századi erődítés egy fa-föld szerkezetú, sövényfonatos paliszád lett volna, míg a korai Árpád-korban egy nagyméretú, szárazon rakott kó köpenyfalazattal ellátott sánccal vették volna körbe a szigetet.

A 9. századi sövényfonásos paliszádnak azonban a sajátos kapuszerkezeten kívül sehol másutt nem találták nyomát, tehát nem a teljes szigetet övező, önálló jelenségről van szó, ahogyan azt Cs. Sós Ágnes megállapította. ${ }^{112}$ Sokkal inkább a déli szigetnyúlványon fekvő udvarházat határolhatta, vagy egy udvarházhoz tartozó építmény maradványa lehetett. ${ }^{113}$ A sáncszerkezet egyes elemeinek és a településszerkezeti összefüggéseknek a felülvizsgálata révén felmerült annak lehetősége, hogy az eddig két külön erődítésként kezelt, a 9. századra és a 11. századra keltezett maradványok valójában egyetlen védmú részét képezték. A várfalátvágások metszetei a déli tömbben és az északi szigetszélen nagyon hasonló szituációt mutatnak, többé-kevésbé egységes konstrukcióról tanúskodnak: a kettős (vagy hármas) cölöpsor közé fogott, rost- vagy rácsszerkezet alapozású, döngölt földbázisú sánc külső síkját szárazon rakott kőfallal köpenyezték. ${ }^{114} \mathrm{Ez}$ a szerkezet az Árpád-kori sáncvárak között idegen, ugyanakkor Kelet-Közép-Európában a 9-10. században elterjedt típus.

A településszerkezeti rétegösszefüggéseket vizsgálva kiderült, hogy a sánc mindenütt 9 . századi objektumok felett húzódik, de soha sem

\footnotetext{
111 HenNing-RUtTKay 2011.

112 Cs. Sós 1973, 112

113 Amint ez az ásatások során már Fehér Gézában is felmerült; lásd Vargha László 1951. december 4. keltezésú jelentését (MNMA); továbbá Cs. Sós 1973, 112.

114 Ugyanakkor nem zárható ki, hogy a köpenyfal későbbi időpontban készült.
} 
rétegez felül Árpád-kori jelenségeket. Az északi szigetszakaszon megfigyelt stratigráfiai viszonyok alapján az is kiderült, hogy a sáncot az Árpád-kort ugyancsak megelózó jelenségek, temetkezések kísérik. A sziget déli nyúlványán feltárt 11. század végi falmaradványok, az északi szigetszélen megfigyelt stratigráfiai viszonyok, a sírcsoportok erődítéshez való viszonyának tisztázása és az előkerült leletanyag alapján, valamint a történeti események figyelembevételével Zalavár-Vársziget „külső vára” nem keltezhető a 11. századra. Építése legalább száz-százhúsz évvel korábbra, a 9. század végére, a 9-10. század fordulójára tehető.

Az eddig kifejtett, régészeti adatokon nyugvó keltezés mellett egy szerencsés véletlen folytán természettudományos vizsgálatra is lehetőség nyílt. 2012-ben a szombathelyi múzeum raktárá- ból egy doboznyi faminta került elő, amelyről a doboz felirata alapján mindössze annyit lehetett tudni, hogy Zalavár-Vársziget 1979-es feltárásából származik. Az egyes cölöpök szám szerinti beazonosítására a dokumentáció alapján nem volt mód, de előkerülési helyük szelvényhez köthetô, ugyanis az adott évben Cs. Sós Ágnes egyetlen helyen vágta át az erődítést. A VS78 kutatóárok (lásd az összesítő térképen, X-szel jelölve: 1. kép) famintáinak dendrokronológiai vizsgálatát Grynaeus András végezte el (lásd jelen tanulmány Függelékét). Vizsgálata a régészeti érveléssel egybehangzó eredményt hozott.

Bár a mostani eredmények egybehangzóan a 9. század végi keltezést erôsítik, az értékelés és a szerkezeti rekonstrukció kizárólag a szigetet övező erődítés újbóli, modern módszerekkel történő kutatásával válhat egyértelmúvé.

\section{FÜGGELÉK}

\section{A ZALAVÁRON 1979-BEN FELTÁRT FACÖLÖPÖK DENDROKRONOLÓGIAI ELEMZÉSE}

\section{GRYNAEUS ANDRÁS*}

A Savaria Múzeum természettudományos gyújteményében évtizedeken át pihent háborítatlanul két doboz, amelyek az 1979. évi zalavári ásatásból származó faanyagot tartalmaztak. ${ }^{1}$ A minták zöme jó megtartású cölöpökból származik. Amint az 1. képen is látható, a 15-20 cm vastag minták mindegyikéből kivágtak egy-egy kis darabot, vélhetően a fafaj meghatározása céljából. A minták csomagolásából és a melléjük tett leletkísérő cédulákból csak sorszámuk és a mintát szolgáltató cölöp mérete derült ki, így előkerülésük pontos helyének visszaazonosítását nem lehetett megoldani.

A mintákon két vizsgálatot végeztünk el: először sztereo-binokuláris mikroszkóp 18-szoros nagyításával a xylotómiai elemzést, azaz a fafaj meghatározását, majd ezt követte a dendrokronológiai elemzés.

A xylotómiai vizsgálat során megállapíthattuk, hogy az összes minta azonos fafajhoz tartozik. A gyuurús likacsú szöveti szerkezet a tölgyfákra jellemző képet mutatott. A nagyméretú szállítóedények a tavaszi pásztában következetesen csak egy-két sorban helyezkedtek el (2. kép). E jegyek alapján fafajukat a kocsányos tölggyel (Quercus robur L.) azonosítottuk. Ez a tölgyféle nedvességkedvelő, így folyó közeli vagy mocsaras élóhelyről származik. Az eddigi kutatások fényében általánosságban megállapíthatjuk, hogy a tölgyfélék használata az újkor előtt tipikusnak mondható Magyarország területén. A lelőhely többi megvizsgált objektuma alapján is dominál a nedvességkedvelő kocsányos tölgy használata.

* Grynaeus András. Magyar Dendrokronológiai Laboratórium, 1021 Budapest Széher út 76/a.; dendro@ludens.elte.hu

1 Ezek az anyagok annak idején valószínúsíthetően Horváth Ernő révén kerültek a múzeumba.
A cölöpök kivágási technikája vegyes volt. Nagyobb részüket a fatörzsek négyzetesre bárdolásával alakították ki, általában úgy, hogy a fa bele a cölöp közepén legyen. Kivételt ez alól az 1. minta képez. Ennél először félbevágták a rönköt, majd ezt bárdolták le négyzetesre, így a fa bele az egyik oldal közepére került. Ennek alapanyaga valószínúleg nagyobb méretú volt, mint a többi, ez indo-

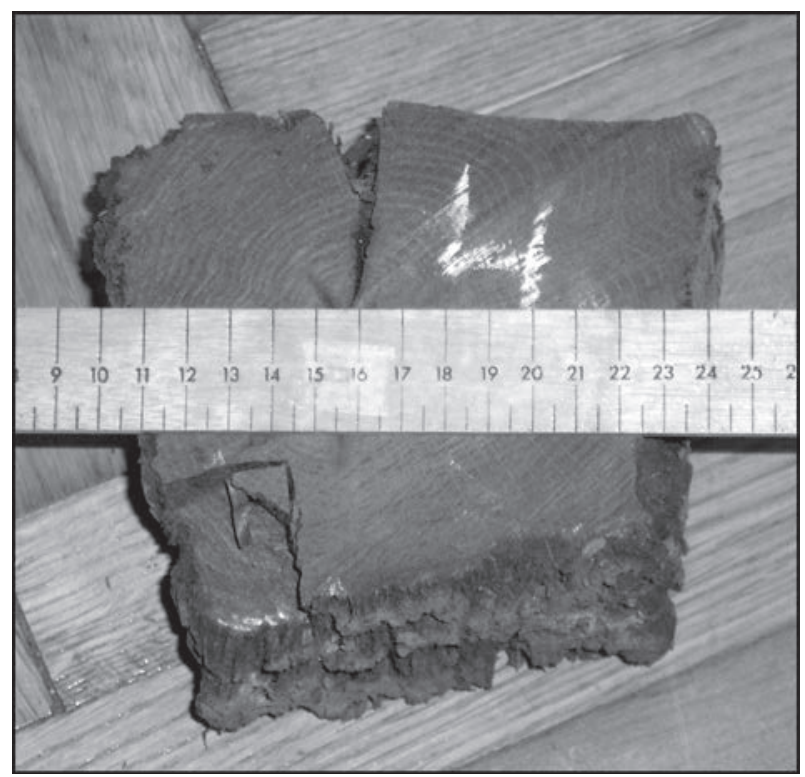

1. kép. Zalavár. 1979-ben kiásott cölöpminta a Savaria Múzeumban

Abb. 1. Zalavár. Probestück eines 1979 ausgegrabenen Pfostens im Savaria Museum 


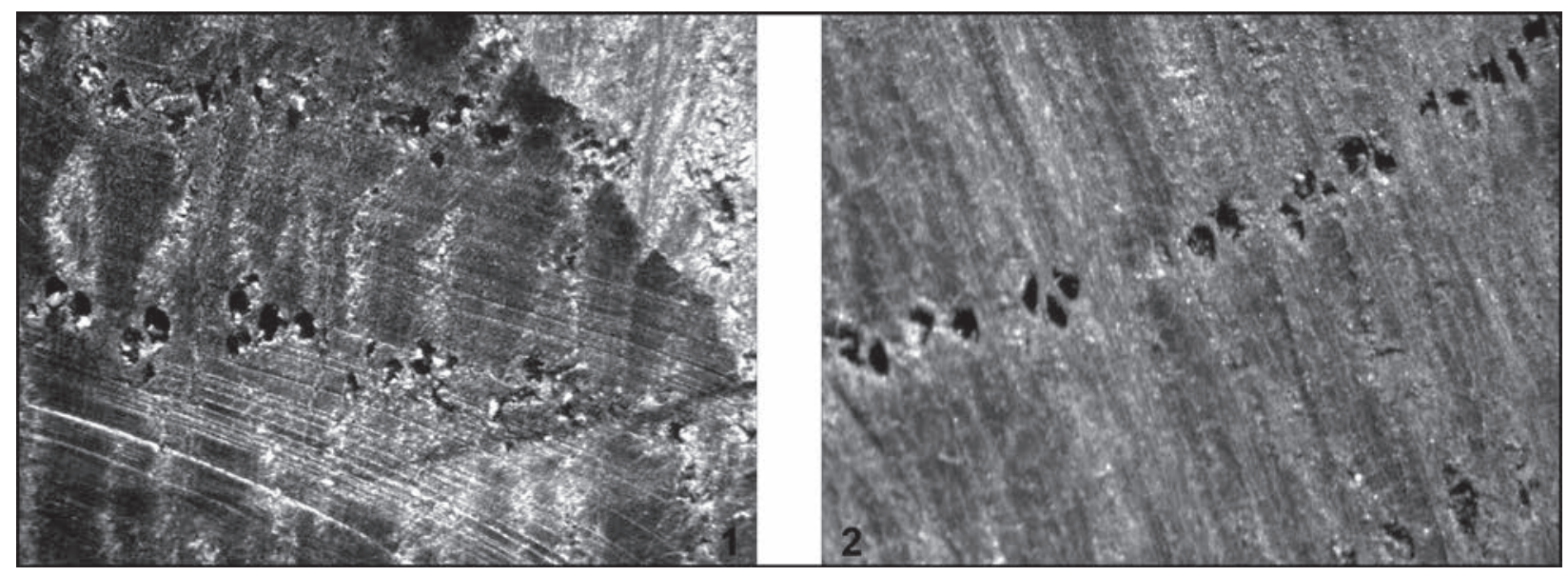

2. kép. Zalavár. 1979-ben kiásott cölöpminták xylotómiai képe. 1: 1. minta; 2: 2. minta

Abb. 2. Zalavár. Das xylotomische Bild der Probestücke von 1979 ausgegrabenen Pfosten. 1: Probe 1; 2: Probe 2

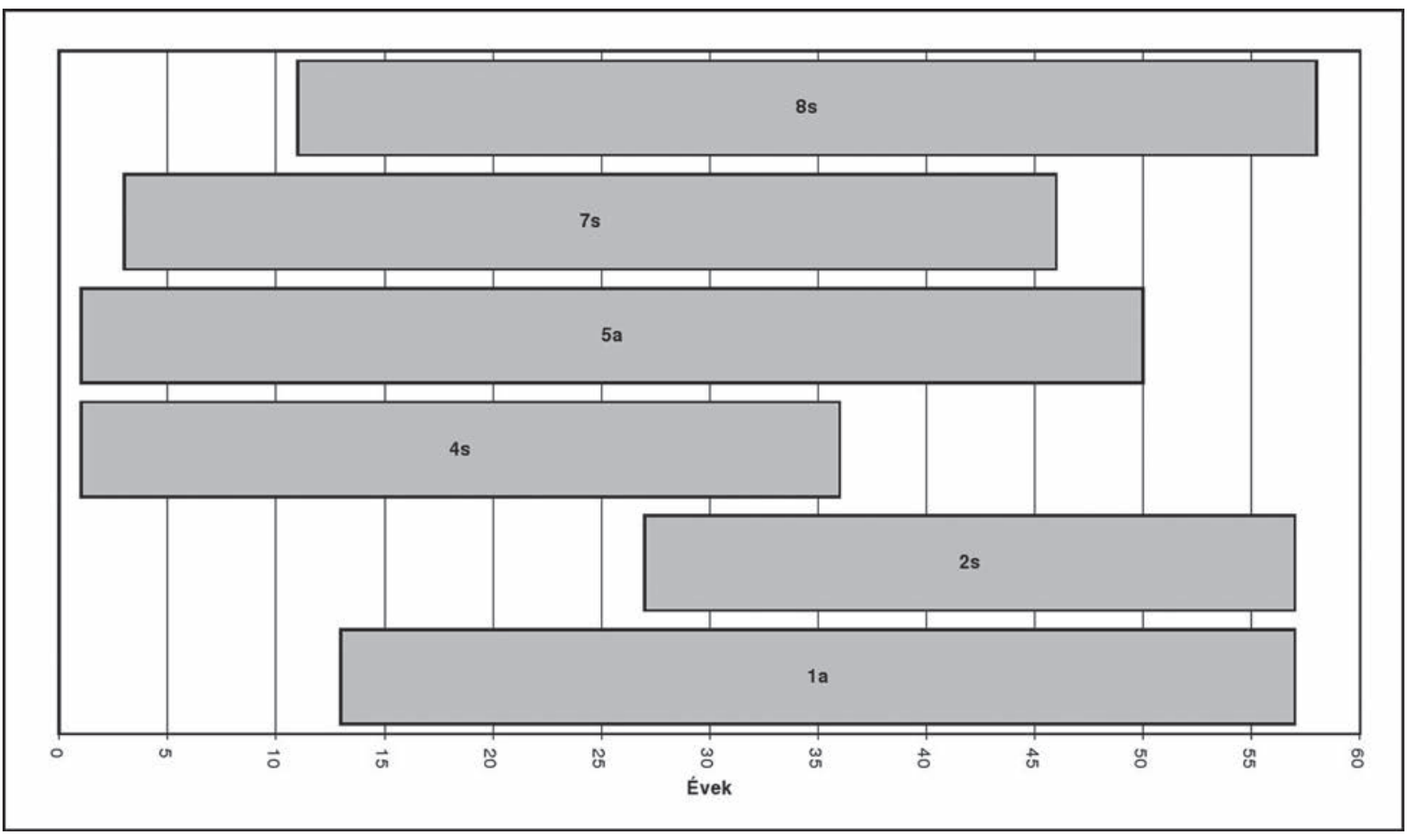

3. kép. Zalavár. 1979-ben kiásott cölöpminták egymáshoz viszonyított kora

Abb. 3. Zalavár. Das relative Alter der Probestücke von 1979 ausgegrabenen Pfosten

kolta ezt a megoldást. A 7. cölöp körcikk keresztmetszetú, míg a 8. minta egy faragás nélküli, félbevágott rönkből származik.

A faanyag további jellegzetessége, hogy fiatal, a ma ideálisnak tartott vágáskort (90-120 év) el nem érő, 50 év körülüli fákat vágtak ki a cölöpök alapanyagául.

A minták egyikén sem figyelhettünk meg kéregmaradványt, és a fa szijácsához tartozó évgyưrúk is következetesen hiányoztak. Valószínúsíthetjük, hogy ezeket a sérülékeny farészeket tudatosan távolították el. Ez a munka minőségére, az elkészítés gondosságára utal, és ante quem típusú keltezést tesz lehetővé.
Az évgyưrúvastagságok lemérését követően, az adatsorok egymással való összevetése során kiderült, hogy a 3 . és a rossz megtartású 6 . minta kivételével évgyưrúvastagság-sorozataik nagyfokú hasonlóságot mutatnak. Egyesített adatsoruk 57 év évgyûrúvastagság-adatait tartalmazza. A minták összehasonlíthatósága vegyes volt, ami arra utal, hogy nem csak egymás közelében álló fákat használtak fel a cölöpök elkészítésekor, hanem egy nagyobb terület fáit vágták ki.

Az egyes cölöpök egymáshoz viszonyított korát a 3. kép ábrája szemlélteti. Az ábráról leolvasható, hogy a nem túl tág határok között mozgó, eltérő életkor ellenére lényegé- 
ben egyidős, vélhetően egyszerre kivágott fákból készültek a megvizsgált cölöpök. Kivágásuk időpontjának meghatározásához az utolsó, 57. évgyuurú által reprezentált évhez hozzá kell adnunk a szijácshoz tartozó minimális évgyứrúszámot, azaz tizenkét évet.

Az elemzés következő lépéseként egyesített adatsorunkat összevetettük a már megvizsgált zalavári objektumokból származó minták adataival. Ez a következő eredményre vezetett: a mostani adatsor záró éve csupán egy évvel idősebb a Nemzeti Múzeum raktárában lévő, a zalavári Vársziget északi részén kiásott cölöpöknél, így beleillik abba a relatív kronológiai rendszerbe, amelyet a Szombathelyen őrzött cölöpök, a 2006-ban feltárt, a salzburgi érsekség területét övezô palánkszakasz, három kút (157/99, 55/99C és 30/01), a Cs. Sós Ágnes által a sziget északi részén kiásott építmény cölöpei és egy további kút (14/03) alkotnak.

Utolsó lépésként a cölöpök egyesített adatsorát az abszolút keltezéssel rendelkező kronológiákkal hasonlítottuk össze. Ez a morva területre a közelmúltban kidolgozott adatsor ${ }^{2}$ esetében értékelhetónek túnő eredményt adott. Mivel nincs adatunk arra, hogy ez a kronológia a Kárpát-medence területéröl származó faanyag esetében mennyire használható, nem dönthető el ennek a keltezésnek a megbizhatósága. A kronológiai egyezést feltételesen elfogadva az adatsor utolsó, 57. évgyúrúje a 867. esztendőben képződött, így kivágására legkorábban 879-ben kerülhetett sor.
Ha helytálló ez a jelenleg csak feltételesen elfogadható keltezés, akkor az említett relatív kronológiai rendszer abszolút dátumokhoz kötve az alábbi módon írható le, minden esetben a legkorábbi kivágási időpontot figyelembe véve: legkorábban a 2006-ban feltárt (a salzburgi érsekség területét övező) paliszádszakasz faanyagát vágták ki, valamikor 839 után. Húsz év elteltével (859 után) egyszerre vágták ki azokat a fákat, amelyekből három kút létesült a Várszigeten. Újabb huszonegy év eltelte után, azaz 880 után vágták ki azokat a fákat, amelyek felhasználásával épült a Cs. Sós Ágnes által a sziget északi részén kiásott, minőségi faanyagból épített objektum. Jelenleg nem áll rendelkezésünkre olyan adat, amely révén ezt az építményt ennél pontosabban azonosítani lehetne, de elképzelhető, hogy a területen feltárt és erődítményként emlegetett építményről van szó. Újabb két év eltelte után (882 után) vágták ki a negyedik kút deszkázatának anyagát. Ismét eltelt öt esztendő (887 után járunk), amikor megépült a Cs. Sós Ágnes által a sziget északi részén kiásott paliszádszakasz, amelyhez újabb fákat vágtak ki.

Az ásatások folytatása és a dendrokronológiai adatsorok szaporodása nyomán idővel eljuthatunk a lelőhely famaradványainak pontos keltezéséhez. Ez a régészeti és történeti kutatás számára fix pontokat adva lényeges és évtizedek óta húzódó viták végére tehet majd - megnyugtató módon - pontot.

\section{IRODALOM}

AHRENS, Claus

1998 Zur Deutung der „Alten Burg“ bei Hollenstedt in Niedersachsen. In: Burgenbau 1998, 79-94.

BEDNÁR, PETER

1998 Die Entwicklung der Befestigung der Nitraer Burg im 9.-12. Jahrhundert. In: Burgenbau 1998, $371-382$. BIALEKOVÁ, DARINA

1998 Zur Bautechnik der Befestigungsmauer der Nitraer Burg im 9.-12. Jahrhundert. In: Burgenbau 1998, 383-390.

BÓNA ISTVÁN

1998 Az Árpádok korai várai. Debrecen.

BRATHER, SEBASTIAN

1998 Karolingerzeitlicher Befestigungsbau im wilzisch-abodritischen Raum. Die sogenannten Feldberger Höhenburgen. In: Burgenbau 1998, 115-126.

Burgenbau

1998 Henning, J.-Ruttkay, A. T. (Hrsg.): Frühmittelalterlicher Burgenbau in Mittel- und Osteuropa. Bonn.

BUZÁs GERGELY

2006 11. századi ispáni várainkról. In: Kovács Gy.-Miklós Zs. (szerk.): „Gondolják, látják az várnak nagy

DONAT, PETER voltát..." Tanulmányok a 80 éves Nováki Gyula tiszteletére. Budapest, 43-53.

1984 Die Mecklenburg - Eine Hauptburg der Obodriten. Berlin.

DostáL, BoŘIVOJ

1975 Břeclav-Pohansko VI. Velkomoravský velmožský dvorec. Brno.

DRESLER, PeTR

2011 Die Befestigung von Pohansko bei Břeclav. In: Macháček, J.-Ungermann, S. (Hrsg.): Frühgeschichtliche Zentralorte in Mitteleuropa. Studien zur Archäologie Europas 14. Bonn, 63-78.

2 A kronológiát a Brnóban klimatikai kutatásokkal foglalkozó Tomáš Kolář állította össze. A közös munkát ezúton is köszönöm neki. 
ETtel, Peter

1998 Ergebnisse der Ausgrabungen auf der Burg Horsadal, Roßtal bei Nürnberg. In: Burgenbau 1998, 137150.

2001 Karlburg-Rosstal-Oberammerthal. Studien zum frühmittelalterlichen Burgenbau in Nordbayern. Frühgeschichtliche und Provinzialrömische Archäologie, Materialien und Forschungen Bd. 5. Rahden/ Westf.

2011 Der frühmittelalterliche Zentralort Karlburg am Main mit Königshof, Marienkloster und zwei Burgen in karolingisch-ottonischer Zeit. In: Macháček, J.-Ungermann, S. (Hrsg.): Frühgeschichtliche Zentralorte in Mitteleuropa. Studien zur Archäologie Europas 14. Bonn, 459-478.

FELD ISTVÁN

2010 Középkori várak és rezidenciák régészeti kutatása. In: Benkő E.-Kovács Gy. (szerk.): A középkor és kora újkor régészete Magyarországon (Archaeology of the middle ages and the early modern period in Hungary). II. Budapest, 495-520.

FELGENHAUER-SCHMIDT, SABINE

2002 Herrschaftszentren und Burgenbau des 10. Jahrhunderts in Niederösterreich. Neue archäologische Forschungen im nördlichen Grenzgebiet. In: Henning, J. (Hrsg.): Europa im 10. Jahrhundert. Archäologie einer Aufbruchszeit. Internationale Tagung in Vorbereitung der Ausstellung „Otto der Große, Magdeburg und Europa“. Mainz, 381-395.

GALUŠKA, LUDĚK

1998 Die großmährische Siedlungsagglomeration Staré Město-Uherské Hradiště und ihre Befestigungen. In: Burgenbau 1998, 341-348.

2008 Die großmährische Siedlungsagglomeration Staré Město-Uherské Hradiště und das Problem ihrer Gliederung anhand der Befestigungen. In: Boháčová, I.-Poláček, L. (Hrsg.): Burg - Vorburg - Suburbium. Zur Problematik der Nebenareale frühmittelalterlicher Zentren. Brno, 169-178.

GERGELY KATALIN

2010 Karoling-kori településrészlet Zalavár-Vársziget úttól északra eső részén. Szakdolgozat, Eötvös Loránd Tudományegyetem, Budapest.

s. a. Erődítéskutatás Zalavár-Várszigeten - Kerámia és keltezés. In: Perémi Á. (szerk.): Hadak útján. A népvándorlás kor fiatal kutatóinak konferenciája XXIII. Veszprém.

GERŐ LÁSZLÓ (szerk.)

1975 Várépítészetünk. Budapest.

GÖMÖRI JÁNOS

2002 Castrum Supron. Sopron vára az Árpád-korban. / Die Burg von Sopron (Ödenburg) in der Árpádenzeit. Sopron.

Heine, HANs-WiLHelm

1998 Frühmittelalterliche Burgen in Thüringen. In: Burgenbau 1998, 151-174.

HENNING, JOACHIM

1998 Neue Ergebnisse - Neue Fragen. Bemerkungen zu Stand und Perspektiven der Forschungen zum frühmittelalterlichen Burgenbau in Mittel- und Osteuropa. In: Burgenbau 1998, 441-447.

HENNING, JOACHIM-RUTTKAY, MATEJ

2011 Frühmittelalterliche Burgwälle an der Donau im ostmitteleuropäischen Kontext: Ein deutschslowakisches Forschungsprojekt. In: Macháček, J.-Ungerman, S. (Hrsg.): Frühgeschichtliche Zentralorte in Mitteleuropa. Studien zur Archäologie Europas 14. Bonn, 259-288.

HEROLD, HAJNALKA

2008 Der Schanzberg von Gars-Thunau in Niederösterreich. Eine befestigte Höhensiedlung mit Zentralortfunktion aus dem 9.-10. Jahrhundert. Archäologisches Korrespondenzblatt 38/2, 283-299.

2011 The fortified hilltop site of Gars-Thunau and the settlements of the 9th and 10th centuries AD in Lower Austria. In: Macháček J.-Ungermann, S. (Hrsg.): Frühgeschichtliche Zentralorte in Mitteleuropa. Studien zur Archäologie Europas 14. Bonn, 519-528.

Heussner, KarL-UWe-WestPhal, THORSTEN

1998 Dendrochronologische Untersuchungen an Holzfunden aus frühmittelalterlichen Burgwällen zwischen Elbe und Oder. In: Burgenbau 1998, 223-234.

HLADÍK, MAREK

2012 Severozápadná brána a opevnenie na predhradí hradiska Miklučice-Valy (The North-western Gate and Fortification in the outer bailey of stronghold Miklučice-Valy). Přehled výzkumů 53/2, Brno 39-67.

HLADík, MAREK-MaZUCH, MARIAN-POLÁČEK, Lumír

2008 Das Suburbium des Burgwalls von Mikulčice und seine Bedeutung in der Struktur des Siedlungskomplexes. In: Boháčová, I.-Poláček, L. (Hrsg.): Burg - Vorburg - Suburbium. Zur Problematik der Nebenareale frühmittelalterlicher Zentren. Brno, 179-212. 
ITM

1999 Poláček, L.-Dvorská, J. (Hrsg.): Internationale Tagungen in Mikulčice V. Probleme der mitteleuropäischen MORDOVIN MAXIM

Dendrochronologie und naturwissenschaftliche Beiträge zur Talaue der March. Brno.

2010 A vártartomány-szervezet kialakulása a kelet-közép-európai államokban. 10-12. századi központi várak a Cseh, Lengyel és Magyar Királyságban. Doktori disszertáció, Eötvös Loránd Tudományegyetem, Budapest.

2013 A honti ispánsági vár kutatása 2011-ben (Die Forschung des Gespanschaftsburg von Hont im Jahre 2011). Communicationes Archaeologicae Hungariae (Budapest) 2010-2013, 123-149.

MÜLlER, AdRIAAN VON-MÜLLER-MUČI, KLARA VON

1983 Die Ausgrabungen auf dem Burgwall in Berlin-Spandau. Berliner Beitäge zur Vor- und Frühgeschichte. Neue Folge, Bd. 3. Berlin.

MÜLlER RÓBERT

1994 Karoling udvarház és temetője Zalaszabar-Borjúálláson. In: Kovács L. (szerk.): Honfoglalás és régészet. Budapest, 91-98.

2010 Die Gräberfelder vor der Südmauer der Befestigung von Keszthely-Fenékpuszta. Castellum Pannonicum Pelsonense Vol. 1. Budapest-Leipzig-Keszthely-Rahden.

Müller-Wille, Michael (Hrsg.)

1991 Starigard-Oldenburg: ein slawischer Herrschersitz des frühen Mittelalters in Ostholstein. Neumünster. NÉMETH PÉTER

1973 Előzetes jelentés a szabolcsi Árpád-kori megyeszékhely régészeti kutatásának első három esztendőjéről 1969-1971 (Vorläufige Mitteilung über die ersten drei Forschungsjahre im árpádenzeitlichen Komitatssitz Szabolcs 1969-1971). Archaeologiai Értesítő (Budapest) 100, 167-179.

NOVÁKI, GYULA

1964 Zur Frage der sogenannten „Burgwälle“ in Ungarn. Acta Archaeologica Academiae Scientiarum Hungaricae (Budapest) 16, 99-149.

NOVÁKI, GYULA-SÁNDORFI, GYÖRGY

1981 Untersuchungen der Struktur und des Ursprungs der Schanzen der frühen ungarischen Burgen. Acta Archaeologica Academiae Scientiarum Hungaricae (Budapest) 33, 133-160.

NOVÁKI GYULA-SÁRKÖZY SEBESTYÉN-FELD ISTVÁN

2007 Borsod-Abaúj-Zemplén megye várai az őskortól a kuruc korig. Magyarország várainak topográfiája 1. Borsod-Abaúj-Zemplén megye régészeti emlékei 5. Budapest-Miskolc.

Přichystalová, RENÁTA

2011 Die Bestattungen in Břeclav-Pohansko. Alte und neue Ausgrabungen. In: Macháček, J.-Ungerman, S. (Hrsg.): Frühgeschichtliche Zentralorte in Mitteleuropa. Studien zur Archäologie Europas 14. Bonn, 35-61.

PROCHÁZKA, RUDOLF

1998 Zur Konstruktion der Wehrmauer der slawischen Burgwälle in Mähren. In: Burgenbau 1998, 363-370.

2009 Vývoj opevnovaci techniky na Moravě a v českém Slezsku v raném středověku. Die Entwicklung der RiTOÓK ÁGNES Befestigungstechnik in Mähren und Tschechisch-Schlesien im Früh- und Hochmittelalter. Brno.

2001 Zalavár Árpád-kori erődítései. In: Gróf P.-Varga K. (szerk.): Örömzenélés. Kovalovszki Júlia tiszteletére. Kézirat gyanánt, egy számozott példány. Budapest.

2005 Zalavár-Kápolna: egy temetőelemzés lehetőségei és eredményei (Zalavár-Kápolna: Possibilities and results of a cemetery analysis). Opuscula Hungarica (Budapest) 6, 173-182.

2010 Zalavár-Vársziget az Árpád-korban. A régészeti kutatások eredményei. Doktori disszertáció, Eötvös Loránd Tudományegyetem, Budapest.

2014 The Benedictine monastery of Zala/Zalavár (County Zala). In: Heinrich-Tamáska, O.-Straub, P. (Hrsg.): Mensch, Siedlung und Landschaft im Wechsel der Jahrtausende am Balaton. People, Settlement and Landscape on Lake Balaton over the millennia. Castellum Pannonicum Pelsonense IV. Rahden/Westf., 281-304.

Schicksalsjahr

2007 Schicksalsjahr 907. Die Schlacht bei Pressburg und das frühmittelalterliche Niederösterreich. Katalog zur Ausstellung des Niederösterreichischen Landesarchivs. Zehetmayer, R. (Hrsg.), St. Pölten.

SOMMER, PETR

2000 Heidnische und christliche Normen im Konflikt - Die Vorstellungswelt der böhmischen Gesellschaft im frühen Mittelalter. In: Ruhe, D. von-Spieß, K.-H. (Hrsg.): Prozesse der Normbildungen und Normveränderung im mittelalterlichen Europa. Stuttgart, 161-186.

Cs. Sós, ÁGNES

1963 Die Ausgrabungen Géza Fehérs in Zalavár. Budapest.

1973 Die slawische Bevölkerung Westungarns im 9. Jahrhundert. München. 
1974 Zalavár-Vár. Régészeti Füzetek Ser I. No. 27, 69-70.

1994 Zalavár az újabb ásatások tükrében. In: Kovács L. (szerk.): Honfoglalás és régészet. Budapest, 85-90.

Stadler, Peter-Draxler, Susanne-Friesinger, Herwig-Kutscher, Walter-Priller, Alfred-Rom, Werner-Steiner, Peter -WiLd, Eva Maria

2000 Die Absolutdatierung der urnenfelderzeitlichen und frühmittelalterlichen Wallanlagen von Thunau am Kamp, MG Gars am Kamp, Niederösterreich mit Hilfe von 14C-Daten. Archaeologia Austriaca (Wien) $82 / 83,39-45$.

STAŇA, ČENĚK

1998 Přerov - eine Burg des Boleslaws Chrouby in Mähren. In: Burgenbau 1998, 49-69.

ŠTEFANOVIČOVÁ, TATIANA

1998 Neufunde aus der Bratislavaer Burg. In: Burgenbau 1998, 427-434.

SZAMEIT, ERIK

1998 Zum frühmittelalterlichen Burgwall von Gars/Thunau. Bemerkungen zu den Fortifikationsresten und der Innenbebauung. Ein Vorbericht. In: Burgenbau 1998, 71-78.

SZŐKE BÉLA MiKLÓS

2005 Templom, egyén és közösség a Karoling Birodalom keleti peremterületén (Church, individuals and community on the eastern periphery of the Carolingian empire). Opuscula Hungarica 6. Budapest, 19-30.

2010 Beziehungen zwischen Keszthely-Fenékpuszta und Mosaburg/Zalavár in der Karolingerzeit. In: Heinrich-Tamáska, O. (Hrsg.): Keszthely-Fenékpuszta im Kontext spätantiker Kontinuitätsforschung zwischen Noricum und Moesia. Castellum Pannonicum Pelsonense Bd. II. Budapest-LeipzigKeszthely-Rahden, 431-463.

2011 Pannónia a Karoling-korban. Akadémiai doktori értekezés, Budapest.

2014 The Carolingian Age in the Carpathian Basin: Permanent Exhibition of the Hungarian National Museum. Magyar Nemzeti Múzeum, Budapest.

2015 A Kárpát-medence a Karoling-korban és a magyar honfoglalás. In: Magyar őstörténet. Tudomány és hagyományőrzés. MTA BTK MŐT Kiadványok 1. Budapest, 31-42.

TIPLIC, IOAN MARIAN

2007 Die Grenzverteidigung Siebenbürgens im Mittelalter (10.-14. Jahrhundert). Heidelberg.

TOMKA PÉTER

1987 Régészeti adatok a győri, mosoni és soproni kora középkori sáncvárak történetéhez. Soproni Szemle 40/2, 147-155.

2006 A győri ispáni vár. Castrum 3, 113-116.

UNGER, JOSEF

2004 Hroby v intravilánu jako projev změny náboženství. In: Kožiak, R.-Nemeš, J. (eds): Pohanstvo a krest'anstvo. Zborník z konferencie usporiadanej 5.-6. II. 2003 v Banskej Bystrici. Bratislava.

UNVERZAGT, WILHELM-SCHULDT, EWALD

1963 Teterow - Ein slawischer Burgwall. Berlin.

WOLF MÁRIA

1996 Die Gespanschaftsburg von Borsod (Grabungen 1987-1993). Acta Archaeologica Academiae Scientiarum Hungaricae 48, 209-240.

2001 Északkelet-Magyarország ispáni várai (Burgen der Gespane in Nordostungarn). A Herman Ottó Múzeum Évkönyve (Miskolc) 40, 179-198.

2008 A borsodi földvár. Egy államalapítás kori megyeszékhelyünk. Doktori disszertáció, Szegedi ZOTZ, THOMAS

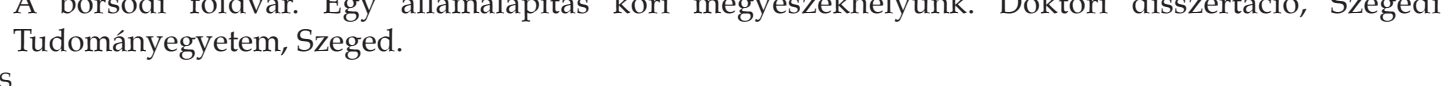

1993 Pfalz, Palast. In: Lexikon des Mittelalters VI. Lukasbilder bis Plantagenet. München-Zürich, 1993-1997. 


\section{DIE BEFESTIGUNG VON MOSABURG/ZALAVÁR ALTE AUSGRABUNGEN - NEUE ERGEBNISSE}

\section{KATALIN Gergely}

Die Befestigung von Mosaburg/Zalavár wurde zum ersten Mal während der ersten Ausgrabungskampagnen in den 1950er Jahren erforscht. Danach hat Ágnes Cs. Sós ab 1973 auf dem nordöstlichen Teil der Burginsel die Fortifikation und einen Siedlungsrest auf längerer Strecke freigelegt (Abb. 1-3). Damals hat man zwei parallele, aus verschiedenen Zeitperioden stammende Befestigungslinien rund um die Insel angenommen. Während die Befestigung aus dem 9. Jahrhundert eine Holz-ErdeDoppelpalisade sein könnte, die durch gestampfte Erde zwischen den zweifachen Pfostenreihen eine Flechtwerkkonstruktion bildete, könnte der sog. „äußere Burgwall“ aus der frühen Árpádenzeit eine große, mit Trockenmauer verkleidete Schanze gewesen sein.

Wir haben aber keinen Beweis für eine Palisade aus dem 9. Jahrhundert, außer der Toranlage im südlichen Teil der Burginsel. Hier kann man also sicherlich nicht über ein um die ganze Insel verlaufendes selbstständiges Phänomen sprechen, wie es Cs. Sós festgestellt hat. Vielmehr könnte es den Herrenhof von Priwina auf dem südlichen Teil der Burginsel begrenzen oder es könnten die Ruinen eines zum Herrenhof gehörenden Bauwerks sein. Nach der Überprüfung der einzelnen Elemente der Schanzkonstruktion und der Zusammenhänge der Siedlungsstruktur scheint es nun möglich, dass die Befestigungsanlagen, welche bisher für zwei verschiedene Befestigungen gehalten wurden (aus dem 9. bzw. 11. Jahrhundert), doch zu einem einzigen großen Wehrbau gehörten. Die Wallabschnitte am nordöstlichen Rand und in dem südlichen Block der Insel zeigen eine sehr ähnliche Struktur, die eine mehr oder weniger einheitliche Konstruktion kennzeichnet: Die zwei- oder dreifachen Pfostenreihen wurden stellenweise mit einer Rostkonstruktion beim Fundament stabilisiert, mit Erde gestampft und von außen mit Trockenmauer geblendet (Abb. 4-5). Diese Konstruktion ist im árpádenzeitlichen Burgenbau unbekannt, vertritt aber einen verbreiteten Befestigungstyp im 9.-10. Jahrhundert in Ostmitteleuropa.
Es ist nach der Analyse der siedlungsstrukturellen Schichtzusammenhänge klar geworden, dass die Befestigung überall über Befunde aus dem 9. Jahrhundert, aber nie über Phänomene der Árpádenzeit läuft. Auf Grund der stratigraphischen Verhältnisse des nordöstlichen Inselrandes stellte es sich heraus, dass die Schanze von aus der Zeit vor dem 11. Jahrhundert stammenden Gräbern begleitet war (siehe Abb. 3).

Die äußere Befestigung von Mosaburg/Zalavár kann also nicht in die Árpádenzeit datiert werden, und zwar auf Grund der Nähe von árpádenzeitlichen Mauerruinen (sog. Pfostenmauer oder innere Burg) auf dem südlichen Vorsprung der Insel; der stratigraphischen Zustände auf dem nordöstlichen Teil der Burginsel; des geklärten Verhältnisses der Gräbergruppen zur Befestigung und der vorgekommenen keramischen Funde (Abb. 6-14); bzw. laut der historischen Ereignisse. Ihr Bau sollte mindestens 100-120 Jahre früher, am Ende des 9. Jahrhunderts oder an der Jahrhundertwende, begonnen haben.

Glücklicherweise stehen uns neben den bisherigen archäologischen Argumenten auch dendrochronologische Ergebnisse zur Verfügung. Im Jahr 2012 kam eine Kiste mit Holzpfosten im Depot des Museums in Szombathely zutage. Von diesen wusste man nur, dass sie auf der Ausgrabung in Zalavár im Jahr 1979 gefunden wurden. Das Arrangement der einzelnen Pfosten war nicht möglich, die Identifizierung des Forschungsgrabens ist aber gelungen, weil Ágnes Cs. Sós in diesem Jahr nur einen Wallschnitt durchgeführt hat. Die dendrochronologische Analyse der Holzreste aus dem Suchgraben VS78 (siehe Abb. 1, mit X markiert) wurde von András Grynaeus durchgeführt (siehe den Anhang des Beitrags). Das Ergebnis der Analyse unterstützt die archäologischen Argumenten: Die Dendrodaten haben die Befestigung auch auf die 880er Jahre datiert. Trotz dieser Bekräftigung der Neudatierung können gesicherte und endgültige Folgerungen über die Konstruktion und Rekonstruktion der Befestigungsanlage ausschließlich nach neuen, mit modernen Methoden fortgesetzten Untersuchungen erzielt werden. 